Journal of Social Sciences (COES\&RJ-JSS)

ISSN (E): 2305-9249 ISSN (P): 2305-9494

Publisher: Centre of Excellence for Scientific \& Research Journalism, COES\&RJ LLC

Online Publication Date: $1^{\text {st }}$ October 2015

Online Issue: Volume 4, Number 4, October 2015

http://www.centreofexcellence.net/J/JSS/JSS Mainpage.htm

\title{
Arab World's Verdict on Legal Education: The Egyptian CaSe betWeEN STATUS QUO, ASSESSMENT, AND SOME HoPE ${ }^{1}$
}

\author{
Mohamed A. 'Arafa ${ }^{2}$ \\ Islam Attia, Ahmad K. Bastaweesy, and Hassan Salama ${ }^{3}$
}

\begin{abstract}
"People who succeed have momentum. The more they succeed, the more they want to succeed, and the more they find a way to succeed. Similarly, when someone is failing, the tendency is to get on a downward spiral that can even become a self-fulfilling prophecy."
\end{abstract}

Antony Robbins

1 The authors wants to thank and express their sincere appreciation to INDIANA INTERNATIONAL AND COMPARATIVE LAW REVIEW (II\&CLR) team for inviting them to share and contribute this report to this specific issue project of QUALIFICATION MANAGEMENT IN LEGAL EdUCATION ("QMILE") IN THE ARAB WORLD: EGYPT. The authors thanks Devin Hillsdon-Smith and Heather Grimstad for their invaluable comments, suggestions, helpful advice, and his tireless work during the editing process. Special gratitude to Professor Dr. Frank Emmert for his unconditional support and for the chance to participate in this project.

${ }^{2}$ Assistant Professor of Criminal Law and Criminal Justice at Alexandria University Faculty of Law (Egypt); Adjunct Professor of Law at Indiana University Robert H. McKinney School of Law (USA). Ph.D., Indiana University Robert H. McKinney School of Law (2013); LL.M., University of Connecticut School of Law (2008); LL.B., Alexandria University Faculty of Law (2006). Likewise, Professor 'Arafa is a Visiting Professor of Business Law at the Arab Academy for Science, Technology, and Maritime Transport ("College of Business Management"). Moreover, Professor "Arafa is a Domestic Public Mediator under Alternative Dispute Resolution, Indiana Rule A.D.R. 25 (2012); and served as an Associate Trainee Attorney and Executive Attorney Assistant at 'Arafa Law Firm (2007). Recently, he has been named to the editorial board of the UNITED STATES-CHINA LAW REVIEW as an "Honored Reviewer." Of course, all errors remain the author's. For any comments or questions, please contact the authors at marafa@iupui.edu, islamattia144@gmail.com, aknewmw@yahoo.com, and hassan thestaryboy@yahoo.com.

${ }^{3}$ Diplomat at the Egyptian Ministry of Foreign Affairs. LL.B. and LL.M. (2011-2014), Alexandria University Faculty of Law (The views expressed here are solely those of the author); Junior Judge at the Egyptian State Council. LL.B. and LL.M. (2011-2014), Alexandria University Faculty of Law, and Junior Judge at the Egyptian State Council. LL.B. and LL.M. (2012-2014), Alexandria University Faculty of Law.

4 See generally Anthony Robbins, Unlimited Power: The New Science of Personal ACHIEVEMENT (2003). (explaining the seven success traits that people who succeed have cultivated in themselves to give them the fire to do whatever it takes to succeed, time and time again) ("The 7 traits of successful people are: Passion, Belief, Strategy, Clarity of Values, Energy, Bonding of Power, and Mastery of Communication ...."). 


\begin{abstract}
:
In the Arab World, especially Egypt, Supreme [Higher] Education Development ("HED") has always been underestimated by the governing authorities, being perceived to be no more than a problem needing some attention and courtesy. Since the fourth decade of the 20th Century, there have been influential actions and powerful movements towards broadening access to higher education through establishing universities and other higher education institutions. Despite the significance of higher education development as a necessary requirement for achieving comprehensive progress, the public expenditure on higher education has decreased in the past few years to reach unaccepted ratios which cannot suffice to achieve any kind of reform. However, due to the permanent budget deficit, it has become a necessity to out additional sources of funding besides rationalizing the public expenditure devoted to each institute. This report surveys in its first part on the legal education in Egypt and other Arab countries. The second and third part of this report discuss in further details the legislative, regulatory, and institutional framework on legal education in addition to the admission procedures. In part four, the report highlights the internal rules, regulations, and resources of the universities and law Schools including the assessment of the faculty member, student, institution, etc. Finally, the report will provide and offer some future proposals to enhance the qualification and the managerial system of legal education in Egypt and the Middle Eastern nation in the light of their revolutions, as they are designing their constitutions.
\end{abstract}

\title{
Keywords:
}

Legal Education, Egyptian Constitution, Law Schools, Exams, Learning and Communication Skills, Legal Writing, Legal Analysis, Cases, Laws, Islamic Law, Civil Law System, Common and Case Law

\section{Citation:}

Arafa, Mohamed A.; Attia, Islam; Bastaweesy, Ahmad K.; Salama, Hassan (2015);; Arab world's verdict on legal education: The Egyption case between status quo, assessment, and some hope; Journal of Social Sciences (COES\&RJ-JSS), Vol.4, No.4, pp: 964-1005.

\section{http://dx.doi.org/10.17632/rvppxyx83r.1}




\section{INTRODUCTION AND OVERVIEW}

In Egypt, Supreme [Higher] Education Development ("HED") has always been underestimated by the governing authorities, being perceived to be no more than a problem needing some attention and courtesy. However, it is no exaggeration to say that enhancing higher education quality particularly legal education is the fundamental prerequisite for achieving political, economic, social, and even cultural reform especially after the "Arab Spring" Uprisings in the Middle Eastern region (Arafa, 2011). ${ }^{5}$ Since the fourth decade of the $20^{\text {th }}$ Century, there have been influential actions and powerful movements towards broadening access to higher education through establishing universities and other higher education institutions (Magehad, 2013). ${ }^{6}$ Although the government has, to some extent, managed to achieve quantitatively better situation, most of these institutions was established without providing adequate physical and human resources and without fulfilling the requirements for a suitable and sufficient education quality (Report, 2015). ${ }^{7}$ In this regard, the educational system, in Egypt, is composed of

${ }^{5}$ See generally Mohamed 'Arafa, Towards a Culture for Accountability: A New Dawn for Egypt, 5 PHOENIX L. ReV. 1 (2011) (discussing the causes of the January $25^{\text {th }}$ Egyptian Uprising, its events, and proposing a new agenda for political, economic, social, and cultural transformation in Egypt). For further details on this point, see generally Amr Shalakany, 'I Heard It All Before:' Egyptian Tales of Law and Development, 27 THIRD WORLD QUARTERLY 5 (2006) ("This article provides a brutally condensed history of the Egyptian legal elite, tracing their rise to power following the introduction of legal reforms in the late 19th century, their fall in the 1950s, and the possibility of a renewed elite status based on 'rule of law' reforms introduced since the 1990s."). Professor Shalakany argued that: ("rule of law' [r] eforms had a considerable effect in raising the profile of Egyptian [legal] practitioners and empowering them as instrumental decision makers on multiple questions of public concern. In particular, ... that the history of the Egyptian legal elite makes it very difficult to either embrace the rule of law as a panacea or dismiss it out of hand as a colonial ploy.").

${ }^{6}$ It should bear in mind that the total number of students enrolled in higher educational institutions has reached 2.1 million students in 2011-2012. See Ahmad H. Magehad, EDUCATION IN EGYPT-FACTS AND OPINIONS, [Periodic Arabic Report prepared by The Egyptian Cabinet, Information and Decision Support Centre] (Mar. 2013) [hereinafter EGYPT PERIODIC REPORT], at http://www.idsc.gov.eg/Publications/PublicationDetails.aspx?typeid=4\&id=327. See also THE WORLD BANK, Arab Republic of Egypt: Improving Quality, Equality, and Efficiency in the Education Sector MNSHD Human Development, DePARTMENT MIDDLE EAST AND NORTH AFRICA Region Fostering a COMPETENT Generation OF Youth, June 29, 2007 http://wwwwds.worldbank.org/external/default/WDSContentServer/WDSP/IB/2008/06/26/0003349 55 20080626033032/Rendered/PDF/428630ESWOP08910gray0cover01PUBLIC1.pdf (last visited Jan. 20, 2015).

7 See Galal Abdelhamid, Higher Education in Egypt Country Review Report, The Strategic

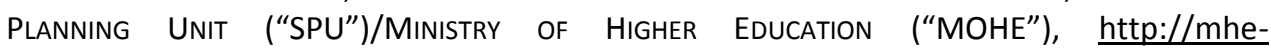
spu.org/site/uploads/resources/Higher Education in Egypt Country Review Report E nglish.pdf, at 27 (last retrieved Jan. 20, 2015). (“According to "The Education For All 966 
three stages. The first phase is basic and fundamental education comprising six (6) years of elementary [primary] education and three (3) years of intermediate [preparatory] education and the second stage is the secondary education [High School] which entails both common-Public and technical education, and the third or the final one is supreme (higher) education including universities and other higher academic and research institutions (El-Sheekh and Tarek, 2013). ${ }^{8}$ In the same vein and at a macro-level, in parallel to the public education, there are private and religiously oriented schools as $\mathrm{Al}$ Azhar or Catholic schools. ${ }^{9}$

The al-majlis al'a'laa(h) lil al-gama'aat (Supreme Council of Universities ("SCU”)) and the Supreme Council of Private and Indigenous Universities ("SCPIU") are the main governing bodies of higher education under the Ministry of Supreme (Higher) Education ("MHE") which governs the whole system of advanced and higher education according to the Universities Regulation Law No. 49 of 1972 and its subsequent amendments in addition to the Law No. 12 of 2009 on the Private and Indigenous Universities which

Monitoring Report 2008," Egypt's Gross Enrollment Rate in higher education (27.29\%) is good compared with other Arab states (which averaged 21\% in 2005) and developing countries in general (average GER of 17\% in 2005). On the other hand, the average GER in developed countries was $66.1 \%$ in 2005 , which shows the amount of work still required for Egypt to achieve similar rates.").

${ }^{8}$ Sara El-Sheekh and Sherif Tarek, Egypt's Public School System: Failing All Tests, AHRAMONLINE, Sep. 30, 2013, http://english.ahram.org.eg/News/82499.aspx (last retrieved Jan. 20, 2015) ("Education workers and parents say public education needs efficient spending, improved facilities and fair wages to tackle long-standing problems. . . . Complaints are not limited to underpaid teachers and private tuition, but are also rife regarding poor facilities and the lack of investment in developing and refurbishing public schools. Ibn Khaldoun, considered to be an average public school, is testament to this state of affairs. Paint flakes off the walls and there is a broken window. Around twenty desks are placed in rows, each shared by up to four pupils in overcrowded classrooms. Some of the benches are broken, and there is barely enough room to pass between the desks. The school has thirty classrooms, all of which are in the same condition. There are up to 2,000 students, with some classes crammed with ninety pupils. . . Egypt is ranked last out of 148 countries surveyed in the 2012-2013 Global Competitiveness Report, published by the World Economic Forum, for the quality of its primary education, falling behind many Arab, African, Asian and Western nations. . . Estimated at 82.5 billion EGP (\$11.9 billion), the 2013-2014 Egyptian education budget is equivalent to 4 percent of GDP, according to the Ministry of Finance. It surpasses the 2012-2013 budget by 15.9 billion EGP and comprises 11.9 percent of the 2013-2014 state budget, estimated at 692.4 billion EGP (around \$100.4 billion).").

${ }^{9}$ Al-Azhar education, which places some emphasis on religious studies, is considered to be the world's oldest university and prestigious institution in Islamic legal studies and religious sciences still operating as it was created by the Fatimid in 988 AD. 
determine the authorities and responsibilities of each entity ensuring a satisfactory level of coordinating. ${ }^{10}$

Despite the significance of higher education development as a necessary requirement for achieving comprehensive progress, the public expenditure on higher education has decreased in the past few years to reach unaccepted ratios which cannot suffice to achieve any kind of reform. ${ }^{11}$ Recent data and statistics show that public expenditure of higher education was estimated to be $0.9 \%$ of the Gross Domestic Product ("GDP") in 2011 and 2012 compared to $1.2 \%$ in 2006 and 2007. ${ }^{12}$ Auspiciously, the new Egyptian Constitution of 2014 stipulates that:

The State grants the freedom of scientific research and encourages its institutions as a means to achieving national sovereignty, and building a knowledge economy. The State sponsors researchers and inventors, and allocates a percentage of government expenditures that is no less than $1 \%$ of Gross National Product to scientific research. It will gradually increase until it reaches global rates. The [State] commits to provide effective means of contribution for the private and public sectors and the contribution of expatriate Egyptians to the development of scientific research . . . public expenditure on scientific research may not be less than $1 \%$ of the Gross National Product and gradually increase to reach the international ratios ${ }^{13}$

However, due to the permanent budget deficit, it has become a necessity to out additional sources of funding besides rationalizing the public expenditure devoted to each institute. ${ }^{14}$ Law is the key to bringing about social stability, promoting economic system, protecting public rights and freedoms with the final, major purpose to achieve justice

10 See generally Law No. 49 of 1972 on UNIVERSITIES REgULATION AND SUBSEQUENT AMENDMENTS \& LAW No. 12 OF 2009 on PRIVATE AND INDIGENOUS UNIVERSITIES, Al-Jaridaa(h) AlRasmiyyaa(h) [THE OfFICIAL GAZETTE] (Egypt).

${ }^{11}$ According to the Egyptian de facto Constitution of 2012, education is free at its all stages, in all the educational institutions owned by the state. See CONSTITUTION OF THE ARAB REPUBLIC OF EGYPT, Dec. 27, 2012, at art. 58 (Egypt), http://www.sis.gov.eg/newvr/theconistitution.pdf.

${ }^{12}$ See EgYPT PERIODIC REPORT, supra note 6, at 7.

${ }^{13}$ In this respect, "the State shall gradually implement its commitment to the allocation of the minimum government expenditure rates on education, higher education, health and scientific research that are stipulated in this Constitution as of the date that it comes into effect. It shall be fully committed to it in the State budget of the fiscal year $2016 / 2017$. The state commits to providing compulsory education until the completion of the secondary stage in a gradual manner to be completed in school year 2016/2017." See Constitution of the Arab Republic of Egypt [EG], Jan. 18, 2014, Arts. 23 \& 238, http://www.sis.gov.eg/Newvr/Dustor-en001.pdf.

${ }^{14}$ See El-Sheekh \& Tarek, supra note 8. 
through building a powerful legal system based on the principle of rule of law. ${ }^{15}$ Hence, such a legal system necessitates an effective legal education as law schools' alumni are responsible for its consolidation through working as attorneys, judges, diplomats, and in various legal departments in all ministries and governmental agencies in addition to private sector, as promoting legal education's quality should have extremely increasing priority among the objectives of the public policy (Shalakany, 2006). ${ }^{16}$

Legal education confronts pressing challenges relevant to the three main elements of the educational process (Youssef, 2005). ${ }^{17}$ First, Faculty member's income is considered insufficient and consequently, he (or she) usually resorts to work multiple jobs to reach a reasonable income which negatively touch the required effort for teaching and research. ${ }^{18}$ In addition, he (or she) may lack stimulus for self-improvement as he/she is not subject to any kind of evaluation except various number of paperwork and documents required for getting promoted. ${ }^{19}$ Secondly, for the law student, he (or she) usually loses confidence in the significance and value of legal education in parallel with increasing anxiety about his (or her) opportunity to get an appropriate job and about his or her future in general and of course, this is attributed to the fact that, after graduation, he/she finds himself/herself obliged to compete with hundreds of thousands of graduates for obtaining a relatively

\footnotetext{
${ }^{15}$ Shalakany, supra note 5.

${ }^{16} / d$.
}

${ }^{17}$ See generally Karim Y. Youssef, The Fall and Rise of Legal Education in Egypt, AL-AHRAM WEEKLY ONLINE, Feb. 10, 2005, http://weekly.ahram.org.eg/2005/729/eg7.htm (last visited Jan. 20, 2015) ("Today, Egyptian faculties of law, even the most prestigious such as at Cairo, Ain Shams and Alexandria University, no longer attract bright or elite students. Most law students are forced into legal studies by their low high school diploma scores. What has happened to the once "faculty of ministers," elites, and history-makers of Egypt? In the not too distant past, Egyptian law schools yielded judges of great integrity, pioneering law professors and lawyers occupying leading positions in the national and international legal field. Take for example Saad Zaghlul, judge and father of the 1919 civil revolution, Ibrahim Shihata, member of the General Council of the World Bank, M. Cherif Bassiouni, the mastermind behind the recently established International Criminal Court and Fouad Riad of the ICTY (International Criminal Tribunal for Former-Yugoslavia.").

${ }^{18} / d$.

${ }^{19}$ Id. ("University system overwhelmed with students naturally placed the majority of these thousands in non-scientific faculties where all that is needed to teach is a microphone and stadium-like- classroom. Hence, the faculties of law and commerce were direct victims. This disastrous admission policy is responsible for the "dark side" of Egyptian legal education. An immense student body leads to oversimplification of teaching, intellectual divorce between professor and students, outdated museum-likelibraries and memorise-recite-only exams. And since to grade the number of assignments produced by these numbers of students would require an army of professors, assignments are frequently graded by junior members of staff according to pre-supplied, standard-form answers!"). 
limited number of jobs whether in the public or private sector. ${ }^{20}$ His or her feelings get worse as the law school does not provide him with the legal skills required to practice any legal profession. ${ }^{21}$ Finally, for the law school, due to insufficient budget, it lacks enough and adequate educational resources especially physical ones such as buildings, classrooms. . . .etc in addition to research ones such as libraries and computer labs. ${ }^{22}$ Furthermore, the overcrowded classrooms besides the largely theoretical curriculum depending on rote learning, and the very outdated subjects of study which do not cope with the modern international standards, have always been too discouraging for students to effectively participate in an operative educational process. ${ }^{23}$

On the other hand, legal education has some pros. First, most of the faculty members of the law schools are qualified enough to contribute to genuine attempts to upgrade the education quality once a suitable strategic plan with determined goals and steps has put into force. ${ }^{24}$ Besides, the staff are considered mega-force which, if properly trained and qualified, would perform an essential role regarding the desired progress. Moreover, the National Authority for Quality Assurance and Accreditation of Education ("NAQAAE") which is a governmental authority affiliated to the Prime-Minister and in charge of accreditation process for all educational and research institutions in Egypt, has managed to constitute a real milestone concerning enhancing education's quality via its objective and neutral assessment. ${ }^{25}$ Likewise, it has been playing a considerable role in regard to raising awareness of educational quality assurance among the Egyptian academic institutes and the Egyptian society through setting up educational standards and performance assessment indicators, providing technical assistance for all educational institutions. ${ }^{26}$

Accordingly this report surveys in its first part on the legal education in Egypt and other Arab countries. The second and third part of this report discuss in further details the

${ }^{20}$ Id. ("A policy of automatic admission to the bar with no further exams or special preparation--a system not found elsewhere in the world-- made advocacy "the profession of those who had no other profession."'”).

${ }^{21} / d$.

${ }^{22} / d$.

${ }^{23}$ Id. ("Students are forced into a large array of unnecessary courses, such as agricultural law, while essential courses like methodology and reasoning, and international contracts are marginal or nonexistent. Many of the most important currents of thought that have animated legal literature for the past century such as "law and economics" and "law and development" remain beyond the reach of students.").

${ }^{24}$ See Shalakany, supra note 5 , at 842-845.

${ }^{25}$ NAQAAE was established in Nov., 2007 by a Presidential Decree, in compliance with Law No.82 of 2006.

${ }^{26}$ See id. Such an entity should be considered a model to be followed by establishing other institutions following its steps, and taking part in the process of education quality enhancement in law schools. 
legislative, regulatory, and institutional framework on legal education in addition to the admission procedures. In part four, the report highlights the internal rules, regulations, and resources of the universities and law Schools including the assessment of the faculty member, student, institution, etc. Finally, the report will provide and offer some future proposals to enhance the qualification and the managerial system of legal education in Egypt and the Middle Eastern nation in the light of their revolutions, as they are designing their constitutions.

\section{I.OVERVIEW ON EGYPT'S LEGAL EDUCATION: BACKDROP, GOOD OR BAD?}

Generally speaking, legal institutions can divide into two essential sorts. Public (governmental) university established officially by the government for legal research and legal educational purposes such as Alexandria and Cairo Universities. A new public university can be established within a decision issued by the President of the Republic based on a proposal from the Minister of Supreme (High) Education. ${ }^{27}$ The second sort is the private university which is set up for profit as the first goal beside the educational one such as the Russian and Pharaohs Universities. ${ }^{28}$ Studying at the Alexandria law school is divided into three sorts regarding the language used for studying. Studying law and legal courses in Arabic language and this includes the following branches, (a) regular for students nominated by the makteb al-tansiq (coordination office) and they must be engaged in a part time program; (b) ordinary external for the holders of higher credentials provided that they hold a certificate of high school or equivalent; ${ }^{29}$ (c) external for students nominated by the coordination office and the school is committed to provide them with educational knowledge with some fee; ${ }^{30}$ (d) al-t'lim al-mafttouh (open education) and this branch has been established in 2007 for students obtaining a certificate of high school or technical diplomas, and (e) the international educational system for

${ }^{27}$ See generally LAW No. 49 OF 1972, supra note 10, at art. 2.

${ }^{28}$ ("The Ministry of Higher Education one of the state institutions entrusted with the construction of scientific and personal humanity to a broad cross-section of young people, both universities and higher institutes. The ministry in its quest to achieve its goals in building personal together a modern, integrated and able to perform its mission in the community and assume their responsibilities towards their homeland, invoking everything produced by the era of the potential scientific and technical capabilities. If our era is the era of information and communication is no doubt that the international information network (Internet) that the Web, which diverge and branch out to reach all parts of the world is one of the most important secretions of this era, which allows access to information from its source in the moments just a few, brief time, effort and money, and representative of what we can call it the largest bank in the world, participate in and benefit from the services of millions of people in the same time."). See generally http://www.egy-mhe.gov.eg/en/private-universities.

29 See Faculty of Law AleXandria University Student Guide (2013), at 19 (on file with authors).

${ }^{30} / d$. 
international students (whether Arabs or not) and without being bound by the coordination office. $^{31}$

On the other hand, according to the internal policy of Alexandria law school, students have the option to study law and most legal courses either in English or French language. These sections have been created recently since $1999 .{ }^{32}$ According to the same law school policy, the internal regulation provides "that the law school contains the following main curriculum: (a) Islamic law (Islamic jurisprudence); (b) civil law (contracts, torts, employment law, family law from Muslims and Non-Muslims, insurance law); (c) commercial law (business law, maritime law, aviation law, and corporations); (d) procedural law; (e) criminal law and procedures; (f) public law (constitutional and administrative laws); (g) public international law; (h) private international law (conflict of laws and immigration laws); (i) philosophy and history of law, and law and economics (financial and tax laws). ${ }^{33}$ By the same token, the law school grants the Bachelor ("LL.B.") degree in law, graduate diploma, Maters ("LL.M.") and doctoral ("Ph.D.") degrees in law. ${ }^{34}$

Currently, the Egyptian Bar Association ("EBA") required for attorneys' application and joining the bar to be Egyptian, with full legal capacity, reputable, having bachelor degree in law from one of the Egyptian universities or a certificate from a foreign university which is equivalent according to the applicable rules and regulations in Egypt, and do not have any criminal records (especially final verdicts with felonies and(or) misdemeanours of public funds) unless he (or she) rehabilitated, and must pay the required fee and the annual subscription. ${ }^{35}$ Furthermore, the judicial authority law mentions that "whoever wants to be appointed at the public prosecution and become a district attorney (to be soon a judge) must be Egyptian, reputable of more than thirty (30) years old for a trial court with a complete legal capacity, and thirty-eight (38) years old in the appellate court and of forty-one (41) in the Court of Cassation (Supreme Court), holding a law degree and does not have any criminal records against. ${ }^{" 36}$ With regard to the appointment

${ }^{31} / d$.

32 Id. See also the AlEXANDRIA UNIVERSITY FACULTY OF LAW WeBSITE, http://www.law.alexu.edu.eg.

33 See The Internal Regulation No. 1302 of Faculty of LAW AleXANdRia University (1996), at 2-9, at art.1

${ }^{34}$ Id. at art. 2.

35 See LAW No. 17 of 1983 on Legal Counsels, (amended by the Advocates LaW ANd Egypt BAR ASSOCIATION LAW No. 197 of 2008), http://www.ibanet.org/PPID/Constituent/Bar Issues.../ITILS Egypt.aspx, Al-Jaridaa(h) AlRasmiyyaa(h) [THE OfFICIAL GAZETTE] (Egypt), at art. 13.

${ }^{36}$ See Judicial Authority LaW No. 46 of 1972, amended by LAW No. 17 of 2007, AlJaridaa(h) Al-Rasmiyyaa(h) [THE OfFICIAL GAZETTE], 1975, at art. 38 (Egypt). 
of the junior faculty members (teaching or lecturer assistants) (Annual Report 2012), ${ }^{37}$ it is required for the candidate to be good reputation, must have obtained at least "Very Good" Grade (equivalent to the grade of $\mathrm{A}-$ ), according to the European system as an overall grade within his (or her) first law degree (LL.B.) and to be one of the top $10 \%$ of the graduate class, and must have obtained "Good" Grade (equivalent to the grade of B+) at least in his/her area of interest. ${ }^{38}$ It is mandatory for undergraduate students to study the following law courses for their bachelor degree: Civil; Commercial; Maritime; Aviation; Civil and Criminal Procedural; Penal; Criminology and Penology; Constitutional; Administrative; Public and Private International; Family (Muslim and Non-Muslims); financial and tax; History and Philosophy of law, and employment laws. ${ }^{39}$

On the other hand, it is required for a candidate to join the graduate programs to get a Master (LL.M.) degree to hold a bachelor in law from an Egyptian university or an equivalent degree from another accredited institute and a diploma from the graduate studies program. In addition, he (or she) must do a creative research to be accredited by the Supreme University and Faculty councils during one year at least from the date of acceptance and to give a public presentation of the research proposal to be accepted by the defense committee. ${ }^{40}$ In the same vein, it is required for joining the doctoral program that the candidate have received two diplomas, one of them required to be either in public or private law or he (or she) has obtained a Master (LL.M.) degree by submitting a thesis or have had a diploma in public or private law. ${ }^{41}$ Further, the candidate must do creative researches during the first two years of the program from his acceptance's date and do an oral examination of his/her dissertation proposal and to be successfully defended and accepted by the graduate committee. ${ }^{42}$

${ }^{37}$ See The Annual Report of the Faculty of Law AleXandria University (2012), at 20 (on file with authors). Thus, the average of the entire departments and sections during the 20062010 is 4,255 students per year. Regarding the admitted students polls at Alexandria law school, it has been reported that around 2,434 students had been admitted between 2006 and 2010 in the regular section, 168 students in the ordinary external section, 281 in the English section, 38 in the French section and 1,333 in the external section.

${ }^{38}$ See id., LAW No. 49 of 1972, supra note 10, at arts. 135 \& 136.

${ }^{39}$ Id. at art. 3.

${ }^{40} / d$. at art. 31.

${ }^{41}$ Id. at art. 30.

42 Id. at art. 35. It should be noted that there are several law schools, thirteen (13) of them are public (Cairo, Alexandria, 'Ain-Shams, Assuit, Tanta, Mansoura, Zakazeik, Minofyyaa(h), Bani-Sueiff, Banha, Helwan, South Vally, and Sadat). On the other hand, the private law schools are Legal Studies and International Relations at Pharaohs University and Faculty of Law and Political Science at Beirut Arab University. See generally THE EGYPTIAN SUPREME COUNCIL OF UNIVERSITIES, http://www.scu.eun.eg/scu=supremecouncilofuniversities \& THE ALEXANDRIA UNIVERSITY INDEX, http://www.alexu.edu.eg/index.php/ar/. 


\section{II.THE LEGISLATIVE AND INSTITUTIONAL FRAMEWORK FOR LEGAL EDUCATION: STATUS QUO}

Generally speaking, the external legislative framework governing legal education in Egypt based on Act No. 49 of 1972 on Universities Regulation and its executive decree No. 809 of 1975 in addition to the complementary acts and subsequent amendments. ${ }^{43}$ Furthermore, the Private and National Universities Act No. 12 of 2009 and its executive regulation rules, Act No. 82 of 2006 on Establishing the National Agency for Education Quality Assurance and Accreditation ("NAEQAA") and its executive regulations of the Students Unions amended by the Ministerial Decree No. 3613 of $2009 .{ }^{44}$ Moreover, there are distinctive rules and regulations governing legal education, by which each law school has its own internal regulation rule, which comprises detailed rules governing the legal education process in all its aspects. ${ }^{45}$ For example, in Alexandria law school; there exists more than one regulation rule enacted by the Ministerial Decree No. 1302 of 1996 regarding the "Opened Education Program," "The Education In Foreign Language Program," and "The Quality Assurance Unit Internal Regulation Rule."

${ }^{43}$ Id. This act is complemented by the Acts No. 50/1972 and 1975, No. 40/1974, No. $112 / 1959$, No. 100/1992 (and its explanatory memorandum, amended by the Acts No.70/1975, No. 82/ 2000, and No. 84/2012).

44 Act No. 12 of 2009 on Private and National Universities Act No. 12 of 2009, AlJaridaa(h) Al-Rasmiyyaa(h) [The Officlal GAZEtTe 9], Mar. 3, 2009 (Egypt); Act No. 82 of 2006 on Establishing the National Agency for Education Quality Assurance and Accreditation ("NAEQAA"), Al-Jaridaa(h) Al-Rasmiyyaa(h) [THE OfFICIAL GAZETTE 22], June 6, 2006 (Egypt), at http://www.egy-mhe.gov.eg/.

${ }^{45} / d$.

${ }^{46}$ In this regard, it should be noted that Alexandria law school accepts in this educational program the following categories:

(a)Thanaweyaa(h) Ammaa( $h$ ) (High School) certificate or its equivalent holders since at least five (5) years;

(b)Higher Qualifications holders and university graduates, who must have been graduated from High School, and

(c)Foreign students with the same admission general conditions, through the legitimate channels and according to the followed procedures.

See id. at INDEX, supra note 42 \& http://www.alexlaw.edu.eg/html.php?filnavn=shorot.htm. In this regard, it should be noted that teaching in the "English Language Unit" started by the Faculty council resolution in June 25, 1997 and August 11, 1997 for the "French Unit." Article 1 of the aforementioned regulation provides that "the legal basis and establishment: the quality assurance unit in the faculty of law is established according to university council resolution number 26 in the year 2007, and the unit has been activated in July 2007. And this unit is considered an extension for the university performance evaluation unit, and is treated as an administratively independent unit affiliated to the faculty dean." 
Regarding the procedures framework required for the establishment of a law school, Article 3 of the Universities Regulation Act (amended by Act No. 100/1992) stipulates that "the determination and establishment of faculties and institutes should be through a decree from the President of the republic based on a presentation from the competent Minister and after seeking the opinion of the Council of the competent university and the approvals of the universities high council and the ministries council." ${ }^{\prime 4}$ As for the criteria and standards that have to be met, "the duration of the study for a bachelor of law is four years," have a bachelor of law from one of the Egyptian universities, or to have an equivalent degree from another scientific institute recognized by the university, and this is with the standard determined by the internal regulatory rule of each faculty, and to continue the study for a year, according to the rules of this regulatory rule," 49 "it is required, in the student, for having diploma from any of the institutes, to have to have a bachelor of law from one of the Egyptian universities, or to have an equivalent degree from another scientific institute recognized by the university, and to continue the study for two years, and this is according to the rules of this regulatory rule," "it is required, in the student, for having master's degree in law, to have one of the postgraduate diplomas in law, and to make a research in a topic for at least one year, and this is according to the rules of the internal regulatory rule, ${ }^{, 50}$ and finally "it is required, in the student, for having a doctor of law degree, to have master's degree in law, or two postgraduate diplomas one of them in private law or public law, or a specialization diploma from one of the institutes in one of the legal sciences branches and diploma in private law or public law and to make

See also http://law.asu.edu.eg/ \&

http://law.asu.edu.eg/article.php?action=show\&id=7840 (The same rule has adopted a new regulation rule regarding postgraduate studies in 2012). In 'Ain-Shams University law school, there exists the Ministerial Decree No. 830/1996 on internal regulations and in Banha University law school as well in July 2003. On these internal regulations, see generally http://gate.ahram.org.eg/News/246561.aspx; http://www.flaw.bu.edu.eg/; \& http://www.flaw.bu.edu.eg/flaw/index.php/about-faculty/bylaw (last retrieved Jan. 20, 2013). Furthermore, the Lawyer Profession Egyptian Act No. 17 of 1983 and its amendments and Act No. 47 of 1973 and its amendments on Legal Departments in the Public Institutions, Public Agencies, and Their Affiliated Units plays fundamental role in that area. Also there is a set of acts related to the judiciary bodies such as the Supreme Constitutional Court Act No. 48 /1979, Act No. 46/1972 on the Judicial Authority, Act No. 47/1972 on the State Council, Act No. 117 /1958 on Reorganizing The Administrative Prosecution and The Disciplinary Trials in the Egyptian Territory, and the Act No. 75/1963 on Organizing State Cases Agency, http://www.ad.gov.eg/Legislative Section/LawGeneralPost/ \& http://www.ap.gov.eg/.

${ }^{47}$ See id. LAW No. 49 of 1972, supra note 10, at art. 3.

${ }^{48} / d$. at art. 137.

${ }^{49} / d$. at art. 139.

${ }^{50} / d$. at art. 140. 
innovative researches in a topic for at least a two year period, and this is according to the rules of the internal regulation rule." ${ }^{, 51}$

Adding a new degree program in law or significantly changing an existing program is not completely the same. Therefore:

Each faculty and institute affiliated to the university must have an internal regulation rule issued by a decree from the Minister of High Education after seeking the opinion of the faculty council or the institute and the university council and the approval of the universities high council. This regulation rule shows the framework of the faculty or the institute and everything related to its special various internal affairs, and this is within the limits of the law, and according to the framework or the public order shown in the executive regulation rule. The internal regulation rule organizes, in addition to the issues shown in the law and the executive regulation rule, particularly the following:

a.the faculty or the institute partitions and its various interior specializations under it;

b....;

c.specialization branches and scientific degrees and certificates branches in the faculty and the institute;

d.the detailed conditions for having the degrees \& the scientific certificate \& the diplomas from the faculty or the institute;

e.the curriculum of the study, its distribution to the study years and the hours specified for each of them;

f.the study system, registration, examination, conditions of certificates awarding and the discipline in the schools and the institutes affiliated to the faculty ${ }^{52}$

Principally, Article 66 reads that "the internal regulation rules of the faculties show the courses and the distribution of its curriculum on the study years and the number of credit hours specialized for each curriculum. And the competent partition council determines the topics being taught in each curriculum, which is accredited by a resolution from the faculty council." 53 Also, "each faculty must have a guidebook that includes the curriculum content" 54 and the internal regulation rules of the faculties must show the training system for the students in licentiate, bachelor and postgraduate studies sections. $" 55$

\footnotetext{
${ }^{51} / d$. at art. 141.

${ }^{52}$ Id. at art. 197.

${ }^{53}$ Id. at art. 66.

${ }^{54}$ Id. at art. 67.

${ }^{55}$ Id. at art. 68. Finally, Article 92(a) stipulates that "Diplomas are studies dealing with curriculums of practical or academic nature, and its duration is at least one year. And it is possible for the internal regulation rules of the faculties and institutes to include the establishment of one or two year period diplomas in various university faculties and 
On the law schools level, one of the most significant alterations that happened in the bachelor sections, is the establishment of the teaching in foreign languages units along with other momentous changes that happened in the postgraduate studies is the implementation of the credit hours system in various law schools on Egypt. ${ }^{56}$

With respect to the admission procedures, the Higher (Supreme) Education in Egypt is preceded by twelve (12) years of education; nine (9) years of elementary education and three (3) years of secondary (high) education. ${ }^{57}$ This applies to public, private, Al-Azhar education, which places emphasis on Islamic studies. At the end of the secondary education, students have to pass a centralized, national exam (Thanaweyaa $(h)$ Ammaa (h) (high school), in order to get the general secondary education certificate. Then, students are allowed to join higher education institutions through applying to the maktab al-tanseek (Central Placement Office 'CPO'). Students have to fill in an online form (application) enumerating the higher education institutions they are willing to join. ${ }^{58}$ Then, the CPO is the governmental entity responsible for distributing students to universities and other higher academic educational institutions according to the following criteria:

(i) the maximum number of students that can be accommodated by each higher education institute, which is normally decided by the Ministry of Higher Education ("MOHE") and the Supreme Council of Universities ("SCU");

(ii) the rank of the secondary (high) education final exam scores of candidates wishing to enter the same higher education programs; and

(iii) the candidates' own list and ranking of higher education institutions he or she wishes to join (Egypt Review Report, Abdelhamied, 2015).$^{59}$

institutes. ..." Id. at art. 92. Hence, Article 4 of the internal regulation of Alexandria law school stipulates that "faculty council determines, after seeking the competent partition council opinion, the topics being taught in each curriculum" (on the bachelor of law curriculum). Article 6(bis) provides "it is possible through a faculty council resolution the establishment of a branch teaching the curriculum in a foreign language determined between the English and French languages" and "the faculty council must determine at the beginning of each year the judicial practical subjects. ..." , and "the study in each diploma includes, in addition to the specified curriculum shown in the previous tables, a general curriculum or more determined by the faculty council based on the competent partitions request. ..." Id. at art. $17 \& 18$.

${ }^{56}$ Id. See also MINISTERIAL DeCREE No. 830 /1996, at art. 16.

${ }^{57}$ It should bear in mind that Pre-university education is governed by Law No. 139/198, (modified by Law No. 233/1988, Law No. 2/1994, and Law No. 23/1999). Article 4 of Law No. 139/198 indicates that "pre-university education includes nine years of mandatory basic education, divided into a six-year elementary stage and a three-year intermediate stage, and three years of secondary (high school) education."

${ }^{58}$ In this regard, it should be emphasized that students required filling out in the online application (form) through the following website http://www.tansik.egypt.gov.eg/application/.

${ }^{59}$ See Higher Education in Egypt Country ReVIeW Report, supra note 7, at 11. 
It is worth mentioning that the student's place of residence is put into consideration during the process of distributing students among universities and higher education institutes for admission purposes. Each student is obliged to join the school situated in the governorate where he/she resides as long as his/her score in the Thanaweyaa $(h)$ Ammaa(h) (high school) education final exam equals or exceeds the required score for this school. ${ }^{60}$ If there were not such a school, the student would have to be enrolled in a school situated in one of the closest governorates to his or her place of residence. ${ }^{61}$ Unfortunately, this single criterion is the only one adopted in the process of students' enrollment in higher education and academic institutions, as there are no standardized tests or school-based admission exams. ${ }^{62}$ Moreover, law schools and all other higher education institutions have no role concerning to the students' admission process even in determining the number of students to admit, and consequently, law schools have no authority to deny to enroll any candidate as long as he/she fulfils the conditions required by laws and has been nominated by the CPO. ${ }^{63}$

One should bear in mind that the aforesaid admission process fully applies to $\mathrm{Al}$ Azhar educational institutions. Needless to say, any student who obtains Al-Azhar secondary education certificate is bound to join one of $\mathrm{Al}$-Azhar schools, as he/she is not allowed to join public universities. ${ }^{64}$

Over the years, the required score in the high school education final exam used for enrollment in a law school, whether affiliated to public, private or Al-Azhar University has always been relatively low as it ranges from $75 \%$ to $85 \%$ for the literature section and rarely exceeds $88 \%$ in the science section. ${ }^{65}$ This is attributed to the extremely enormous number of students determined to be enrolled in each law school by the Supreme Council of Universities ("SCU") due to the disgraceful misconception that all that is needed to teach students in social sciences' schools such as law schools is a stadium-like classroom (natatoriums) and microphones. Hence, it is not astonishing to know that each law school in Egypt usually admits about 5,000 student per year. ${ }^{66}$

\footnotetext{
${ }^{60}$ Id. at 12 .

${ }^{61} / d$. at 13.

${ }^{62}$ Id.

${ }^{63}$ Id.

${ }^{64}$ Id.
}

${ }^{65}$ A law school affiliated to Al-Azhar University is called the Faculty of Sharie' $a$ and Law. Three law schools are affiliated to Al-Azhar University. For further details, see http://www.azhar.edu.eg/pages/fac boys.htm.

${ }^{66}$ See Higher Education in Egypt Country ReVIeW Report, supra note 7, at 20 (a chart indicating the development of the number of admitted students over the past seven years). 
As for private law schools, according to Article 18 of Law No. 12 of 2009, "the Council of Private and Indigenous Universities ("CPIU") is the entity responsible for determining the number of students to be admitted in each private university and regulating the admission process according to the education quality standards." 67 Private law schools usually require very high tuition fees and much lower score in the high school final exam compared to public law schools, as they are entitled to have admission exams. ${ }^{68}$ However, as their priority is to maximize their profit, private law schools frequently find it sufficient to perform a simple personal interview which does not count much regarding the admission decision. ${ }^{69}$

It is significant to shed light on the admission procedures in other internal modes of education in law schools which includes the "Foreign Languages Section" (English and French), the "Open Education Program," the entasab mowagaah (directed students), entesab $a^{\prime} a d y$ (external education). ${ }^{70}$ The vast majority of admitted students in a law school are enrolled in the Arabic section, but for enrollment in the foreign language sections, each law school has the authority to determine the number of students to be admitted in each section the minimum score in the high school final English/French exam required to be enrolled in these sections in addition to the relatively high tuition fees. ${ }^{71} \mathrm{On}$ the other hand, students whose scores in the high school final exams are a bit lower than the minimum score required to join a certain law school are admitted through a special program called entasab mowagaah and the CPO is in charge of allocating those students among law schools in the same way and according to the same criteria and procedures as the regular enrollment mode. ${ }^{72}$

As for the open and the entesab $a^{6} a d y$ educational modes, the enrollment requirements differs slightly from a law school to another. ${ }^{73}$ However, these requirements

${ }^{67}$ See LAW No. 12 of 2009 on PrIVATE AND INDIgenOus UnIVERSITIES, supra note 10, at art. 18.

${ }^{68} / d$

${ }^{69}$ Faculty of legal studies and international relations at Pharaohs University is the only private law school in Egypt till this moment. See generally http://www.pua.edu.eg.

${ }^{70}$ The internal modes of education at Al-Azhar law schools include the open, internal, and external educational program modes but not entail "foreign languages sections."

${ }^{71}$ For example, Article 4 of the Bylaw of Foreign Language Education Unit at Alexandria Law provides "that each year, the law school council, upon the proposal of the board of directors of foreign language education unit, issues a decision determining the number of students to be admitted in English and French sections from the total number of students enrolled in the first grade." For further details on this bylaw, see generally http://alexlaw.edu.eg/qua/book/lla.pdf (Arabic version).

72 Id. In March 2011, the SCU abolished the entesab mowagah (directed students program). However, in June 2012 the SCU decided to readopt this educational mode again.

${ }^{73}$ Id. For example, Alexandria law school requires obtaining either the general high school certificate, Al-Azhar high school certificate or the vocational education certificate on condition of applying after three years of obtaining such a certificate. In addition, a 
mainly encompass obtaining a certain degree and a paying relatively high tuition fees. ${ }^{74}$ Generally speaking, the admission process in Egypt rarely witnesses cheating or corruption cases due to several reasons. First, enrollment in law schools, whether for regular enrollment or enrollment in other programs, is run through substantive rules and procedures which can be violated only through committing forgery which is considered a serious crime (felony) in the Egyptian Penal Code ${ }^{75}$ Moreover, the governing board of a law school is not capable of infringing the admission rules as the whole process is centrally governed and controlled by the CPO and there are not any standardized tests or admission exams which can be misused as means of favoritism or nepotism.

\section{III.THE INTERNAL RULES, REGULATIONS, AND RESOURCES OF UNIVERSITIES AND LAW SCHOOLS}

The Ministerial Decree No. 1302 of 1996 on issuing the internal regulation of Alexandria law school is mainly emphasized the degrees granted ${ }^{76}$ courses taught, ${ }^{77}$ number of hours/course, ${ }^{78}$ and grading (assessment) standards. $^{79}$ Also, the opened education program regulation explains the admission and registration rules ${ }^{80}$ teaching and examination techniques, ${ }^{81}$ courses taught, ${ }^{82}$ and the administrative, executive, ${ }^{83}$ and

student who obtains the bachelor degree is allowed to apply without stipulating passing a certain period of time. Also, Tanta law school requires obtaining either the general high school certificate or Al-Azhar high school certificate on condition of applying after five years of obtaining such a certificate.

${ }^{74}$ See Regulation DeCree No. 809 of 1975, supra note 43, at art. 89. It should be noted that student enrolled in the external education program usually have the same lectures, curriculum, and exams of the regular students except for some courses which they are not entitled to attend. On the other hand, open education students have distinct curriculum, lectures, and exams.

75 See Law No. 58 of 1937 (Egyptian PenAl Code) (reformed in 1952), Al-Jaridaa AlRasmiyyaa(h) [THe Official GAZETTE], at arts 206-227. (Egypt).

${ }^{76}$ See The Ministerial DeCReE No. 1302 of 1996, supra note 33, at art. 2.

${ }^{77}$ Id. at art. 3

${ }^{78} / d$. at art. 4.

${ }^{79}$ Id. at art. 12.

${ }^{80} / d$. at 2(a).

${ }^{81} / d$. at 9(b).

${ }^{82}$ Id. at 13(c).

${ }^{83}$ Id. at 40 (d). 
financial affairs. ${ }^{84}$ The same internal policy governs the study of law in foreign languages. ${ }^{85}$ Likewise, the QAUIR mainly elucidates the regulatory structure of the unit and its committee's tasks ${ }^{86}$ and the competence and responsibilities of the unit. ${ }^{87}$ The faculty quality assurance unit aims to develop a quality system for the school. ${ }^{88}$ The competence and tasks of the unit are mainly represented in developing mechanisms for establishing internal quality assurance system inside the school including the academic and administrative activities, and authenticating it by the faculty council. ${ }^{89}$ Furthermore, the unit is responsible for developing mechanisms for activating the Internal Auditing in the school for the academic and non-academic activities and for the coordination with the various sections in the school..$^{90}$ Moreover, the unit is responsible for tracking the academic activities, includes the academic standards development, programs and courses of study, academic reports progress, assuring that the academic outcomes are achieving the school's mission and the compliance with the required models and within its time frames. ${ }^{91}$ Besides, the unit follows and revise the faculty self-assessment annual reports and its compliance with the required models and within its deadlines. ${ }^{92}$ In addition, it follows the student assessment techniques, its development, and assuring that the teaching board members are being aware and trained on the emerging and modern assessment approaches. ${ }^{93}$ It is very significant to have much focus on the training needs of the faculty members and staff for developing their abilities and developing a training action plan by internal and external experts and follows up the candidacy of external surveyor for the study program, according to the accredited standards, revise the annual reports and the quality assurance, and the overall educational process. ${ }^{94}$

In Alexandria law school, for example, a typical teaching load of a full-time professor is about thirty (30) hours per week and 360 hours per semester, and 720 hours per year. A full-time (tenured) professor usually teaches in a typical semester about three to four courses. For the LL.B. degree, the student is required to have in his first year around eighteen credits of classes per week and 216 hours per semester ${ }^{95}$ and 432 hours per year

\footnotetext{
${ }^{84}$ Id. at $47(\mathrm{e})$.

${ }^{85} / d$.

${ }^{86}$ Id. at art. 6.

${ }^{87}$ Id. at art. 7.

${ }^{88}$ Id. at art. 4.

${ }^{89} / d$. at $45(3)$.

${ }^{90}$ Id.

${ }^{91} / d$. at art. 7(f).

${ }^{92} / d$. at art. 7(i).

${ }^{93} / d$. at art. 7(ii).

${ }^{94}$ Id. at 7 (ii)(a)(b)(c).

${ }^{95}$ Id. at art. 4.
} 
along with the seminars (Student Guide, 2013). ${ }^{96}$ In the second year, it is required to have around twenty to twenty-two hours per week and 240-264 hours per semester, and 480528 hours per year, and seminars. ${ }^{97}$ In the third and fourth year, $26-28$ (20-22) hours per week and 52-56 (240-264) hours per semester, and 104-112 (480-528) hours per year are required, besides the seminars. ${ }^{98}$ In the same vein, LL.B. degree is available for the student to be enrolled in the English or French Department, ${ }^{99}$ as the student required studying law courses in foreign language. ${ }^{100}$ Also, at Alexandria law school, student has the opportunity to be engaged in any of the programs offered by the Legal Studies Centre which offers a variety of optional courses and trainings. ${ }^{101}$

96 "Each study year includes practical trainings for a period of 2 hours/week ...." Id., at art. 7. See also StUdeNT GUIDE OF AleXANDRIA UNIVERSity LAW SCHOOl StUdENTS (2013), at 23 (chart 3 explains) (on file with authors).

${ }^{97} / d$. (chart 2 explains).

${ }^{98}$ Id. at 24 (chart 1 explains). LL.B. degree, the all and the only courses required are as follows. In the first study year, courses are international organizations, history of law, Introduction to the study of law, criminology, Islamic law, constitutional law I, political economy, English or French language, and seminars. In the second year, courses are Islamic law, obligations I, administrative law, political economy, family law for nonMuslims, public international law, history of Egyptian law, criminal law I, obligations II, English language, and seminars. In the third year, courses are civil law, commercial law I, criminal law II, labour law and insurance, civil procedural law I, Islamic law, public finance and tax legislation, administrative law, legal studies in French or English language, nationality law, and seminars. In the fourth (final) year, courses are principles of Islamic doctrine, maritime and aviation laws, civil procedural law II, private international law, property law, commercial law II, law of criminal procedure, constitutional law II, and seminars. Therefore, it seems that there are no elective courses and that there is a number of required courses, set for each academic year, students must pass and get their LL.B. Id. at 24. In Alexandria law school, in 2013 academic year 2012-2013, the number of enrolment students were 2,982 students in the regular section, nine students in the external one, 203 students in the English section, thirty-one students in the French section, and 1,151 student in the directed external section. See THE ALEXANDRIA UNIVERSITY LAW SCHOOL ANNUAL Report (2012), at 22 (on file with authors).

${ }^{99} / d$.

${ }^{100}$ Id. at http://alexlaw.edu.eg/qua/book/Imd.pdf. (explaining the internal regulation of the center).

${ }^{101}$ The Centre was established by virtue of the university council resolution in Nov. 1986 for the purpose of offering legal and economical services. For example, the centre offers courses in drafting international contracts, arbitration skills, and contract's translation. See generally $\quad$ http://www.alexlaw.edu.eg/html.php?filnavn=mdk.htm; http://www.alexlaw.edu.eg/modules.php?name=News\&file=article\&sid=1405; http://www.alexlaw.edu.eg/modules.php?name $=$ News \& file $=$ article $\&$ sid $=1326$, http://www.alexlaw.edu.eg/modules.php?name $=$ News\&file $=$ article $\&$ sid $=280$ 
The law students have the opportunity to optionally participate in moot courts competitions managed by the school. For example, in April 2011, the school held two moot court competitions in the form of two criminal courts by which one of them was in the morning and afternoon. ${ }^{102}$ Moreover, the law students have the opportunity to participate in moot courts competitions managed by civil society organizations, such as the Alumni of Law Association, International Committee of the Red Cross, Bibliotheca Alexandrina, and Alexandria University, sponsored the Model of International Criminal Court ("MICC") 2011. ${ }^{103}$ It should be noted that Alexandria law school has the first legal clinic in the Egyptian universities, which was established in 2009, through the cooperation program with the Protection Project: Advanced International Studies Institute in Johns Hopkins University under the supervision of the Egyptian Ministry of Justice. ${ }^{104}$ The legal clinic basically works on two major issues, statute's drafting and improvement, and the legal assistance either in the form of single cases or legal convoys. ${ }^{105}$

Alexandria University is keen to encourage students and researchers exchange programs with various foreign universities, in addition to the Egyptian Students Union ("ESU") efforts regarding enhancing these programs, with the intention to reinforce the cultures dialogue. ${ }^{106}$ Also, the university has already scholarship and study grants programs through the co-operation and twining programs with different universities and academic institutions. ${ }^{107}$ In this regard, the SCU has declared the launch of the Singapore

102 See AlEXANDRIA LAW SCHOOL ANNUAL REPORT, supra note 101, at 63 \& 64.

${ }^{103}$ About ninety of law graduates and undergraduates participated in the MICC model, either as a participant or instructor or organizer, after personal interviews which included more than one hundred applicants and this Model was held in English language. (Note, the author diplomat Mr. Islam Attia had participated in this program, http://micc2011.wordpress.com/).

104 In the year 2011-2012, the legal clinic has worked on various fronts, as working on curriculum development, the Arab Charter of Human and Child Rights ("ACHCR"), the judicial cases, briefs, memorandums, and the field visits. (Note, the author diplomat Mr. Islam Attia had participated in this program, http://www.alexlaw.edu.eg/html.php?filnavn=about3eyada.htm \& \& http://www.elwatannews.com/news/details/356414).

${ }^{105} / d$.

${ }^{106}$ As from the latest news, for example, the university is working on encouraging these programs with the European universities. It is worth saying that the European Union ("EU") is offering scholarships programs and grants for joint research projects between the European side and the Egyptian side for the period 2014-2020. See generally http://www.elwatannews.com/news/details/356414

107 See generally http://au.alexu.edu.eg/Arabic/Research/News/Pages/default.aspx; http://au.alexu.edu.eg/Arabic/Research/News/Pages/aaw.aspx;

http://cu.edu.eg/ar/R projects; $\quad$ http://cu.edu.eg/ar/Scholarships; http://cu.edu.eg/ar/Cairo-University-ScholarShips-53.html; http://cu.edu.eg/ar/page.php?pg=contentFront/SubSectionData.php\&SubSectionld=27; 
Cooperation Program Award ("SCPTA") which comprises a number of scientific programs and training courses in various fields in 2014. ${ }^{108}$ Also, Cairo University has the same track. ${ }^{109}$ However, it is worth mentioning that the share of the law schools from the scholarships and scientific grants awarded to the universities could be not ideal. Cairo University law school have various twining programs with Paris I-Panthéon Sorbonne, Paris II-Panthéon Assas, and Paris Dauphine universities in France, hosts the International Business Law Institute which awards the French-speaking students a high-level rehabilitation for two certificates; one from Egypt (Bachelor and Master) and the other from France (Bachelor and Master). ${ }^{110}$ Furthermore, Cairo and Alexandria law schools having a Master (LL.M. program in business and comparative law), the graduate of this program stated that "the program opened the door for many people who would have otherwise been unable to pursue such a degree"111 giving them "the chance to be recognized as well educated and experienced lawyers." $" 112$

One of the main goals of any law school is to support legal research and writing mainly based on innovation and creativity and which contributes to solving society difficulties for the sake of achieving comprehensive national development. ${ }^{113}$ In Egyptian law schools, it is no exaggeration to say that alumni may pass the four year law school without writing a paper or a thesis. ${ }^{114}$ This can be attributed to numerous reasons. First, there is no statutory rule obliging students to write such a paper and most professors find it sufficient to assess students only through a final written exam at the end of the course. ${ }^{115}$ Besides, the assessment process of papers is a too burdensome task due to the enormous number of students. ${ }^{116}$ When students are required to write a thesis or a paper, the faculty

http://egypt.usembassy.gov/pa/pr071109.html;

http://au.alexu.edu.eg/arabic/MediaCenter/News/Pages/s1.aspx, \& http://au.alexu.edu.eg/Arabic/Research/News/Pages/azz.aspx. Also, is the presence of a chance for the university researchers to apply for the German Cultural Exchange Agency (“GCEA") grants for enhancing researchers' visits exchange programs.

${ }^{108}$ Id.

${ }^{109} / d$.

${ }^{110} / d$.

${ }^{111} / d$.

${ }^{112} / d$.

${ }^{113}$ See, e.g., id. (explaining the mission and the purposed of Alexandria law school, http://www.alexlaw.edu.eg/).

${ }^{114}$ See generally ALEXANDRIA LAW SCHOOL ANNUAL REPORT, SUPRA NOTE 101.

${ }^{115} / d$. 
member responsible for the intended course will be the supervisor in all that is related to the paper. ${ }^{117}$ The supervisor provides academic assistance to students through guiding them to the useful references and research materials they can resort to, besides responding all their questions regarding the paper's topic. ${ }^{118}$ The supervisor is responsible for the paper's assessment. It is noteworthy that due to massive student body, the supervisor usually finds it sufficient to evaluate written papers with no chance for students to explain, indicate, or answer any further inquiries about the paper an oral session. ${ }^{119}$

It is disgraceful to state that law schools do not provide any precautions against plagiarism. There is no technical way to help the supervisor check papers for plagiarism purposes. Accordingly, due to the massive number of students, supervisor is rarely able to perform this task by solely and as a result, the net result is that a lot of students find it easy to compile information from various sources, copy and paste them in their papers. The only sanction applicable in case of convicting a student for plagiarism is to deny student's paper (or thesis) and this only implemented to students at the enrolled in graduate (master and doctoral) studies programs. ${ }^{120}$

Under the umbrella of globalization and advanced technology, there is no doubt that the essence of a genuine educational system is to promote the intellectual abilities of a student who is not only able to gather information but also to think creatively, analyze properly, express his (or her) ideas conveniently, understand and explain the intricacies. Almost all courses in Egyptian law schools entirely focus on theoretical knowledge transmission. Regarding the content of the typical legal courses, the professors illustrates all legal theories in detail and, all doctrinal controversies with zero practical application of these theories to practical cases or hypothesis. Professors always mentions the most important opinions for the theory under discussion and students do not have any role in

${ }^{116} / d$. In practice, there are two types of courses; theoretical and practical skills ones. For the ordinary theoretical courses, it is seldom for the lecturer to ask students to write a paper. On the other hand, for practical skills courses, it is more likely for the faculty member to do so and in this case the student's score in the paper will usually constitute the main base for his evaluation for the whole course.

${ }^{117}$ Id. Thus, students have no role in selecting the supervisor of their research. The latter may define a number of topics for students to choose one or allow them to choose whatever topic they want as long as it is related to the main subject of the course.

118 However, students usually encounter lack of resources. For instance, the library may contain non- updated references or treatises. In addition, many law schools, only one computer laboratory provided with a limited number of computers is supposed to serve a student body composed of about 20,000 members.

${ }^{119}$ However, it is possible to orally assess papers of students of English/French sections because of their relatively limited number.

120 The deterioration of quality of papers is attributed to the previously stated factors such as the tremendous number of students compared to the teaching staff, inability of checking papers for plagiarism, lack of educational resources especially research tools in addition to the fact that education process in law schools is based on how to memorize and recite in exams. See HIGHER EduCATION IN EgYPT COUNTRY REVIEW REPORT, supra note 7, at 22 (chart 3.5 explains). 
applying the theory on the real ground and hence, no actual role played by students about the curriculum's content. ${ }^{121}$ The courses are usually delivered in the format of frontal lectures (no Socratic method) in which the professor explains the issues of the textbook. ${ }^{122}$ On the other hand, the students' task is only to understand and memorize the entirely theoretical information, as they rarely need to search for any additional information since all the final exam's questions have their answers in the required assigned textbook. ${ }^{123}$ Practically speaking, students are rarely taught how to write a petition, criticize a theory or a doctrinal opinion, or analyze a court sentence extracting the legal principles adopted and even highlighting its defects, even they never asked to write a paper (thesis) or to give presentations, and therefore, most students do not know the basics of a scientific research. ${ }^{124}$

Regarding the law school's final exam, Article 71 of the Universities Executive Regulation No. 809 of 1975 stipulates that "for the exams of all grades except the final one, the faculty council, upon consulting the competent section council, determines one of the professors of the same section to participate with the professor teaching the course in preparing the written final exam." 125 In addition, "for the final exam's grade, each higher education sector proposes to the SCU the formation of tripartite committee composed of working and former professors to participate with the professor selected by the faculty council to write the exam and the decision of formation of such committees must be issued by the SCU." ${ }^{\prime 26}$ Regrettably, in practice, the previously statutes are not complied with at all. Therefore, the professor of the course is the only one responsible for writing the exam without any participation in doing so, and even without any sort of review regarding the questions formats, the time amount to answer the questions ... etc. and it is not surprising to know that it is possible for an exam to entail a question about some issues which were not explained in class (lectures). Furthermore, the professor is entitled to decide whether the exam would contain theoretical questions, case-based questions, or to entail both, in addition to the format of questions; long essay, short answer, multiple choice questions ...

${ }^{121} \mathrm{Mr}$. Attia (one of the authors) argued that "he had about forty courses. Unfortunately, only one course was not based on a textbook. Instead, collecting the curriculum of the course was the task of students through taking notes during lectures and then searching for the relevant information.").

${ }^{122}$ Regrettably, some professors do nothing but mention the information which already exists in the textbook without any additional examples or detailed demonstration. It is to be noted that the tremendous number of students totally hinder any active interaction between professor and students. Assume a classroom with about 2,000 students having a lecture. If $5 \%$ of them had questions to ask, maybe a whole day would not be enough to answer all of them.

${ }^{123}$ See generally HIGHER EDUCATION IN EGYPT COUNTRY REVIEW REPORT, supra note 7.

${ }^{124}$ Id.

${ }^{125}$ See Regulation DeCReE No. 809 of 1975, supra note 43, at art. 71.

${ }^{126}$ Id. at art. 82. 
etc. ${ }^{127}$ It should be noted that the guidebook for national academic reference standards for law schools has determined that for intellectual skills of alumni, they should be able, inter alia, to analyze facts and connect them together in order to reach a conclusion. ${ }^{128}$ In addition, they should be capable of properly interpreting provisions of law and determining which ones are applicable to the facts besides the ability of criticizing. ${ }^{129}$

Although most law courses are theoretical, the internal regulations of all law schools in Egypt usually dedicate one or two seminars per year for practical and professional legal skills (tamreenat 'amaleyaa $(h)$ ). ${ }^{130}$ This sort of courses is supposed to be case-based ones in which students are taught how to brief cases and how to apply their theoretical study to real facts, enable students to know much more information about the litigation procedures before the courts. ${ }^{131}$ For these purposes, law schools sometimes hire judges to teach such courses. ${ }^{132}$ A law school may have an additional legal skill-based program as legal clinics, however, such program counts nothing regarding students' final grades since it is optional. The guidebook for National Academic Reference Standards for Law Schools determined the practical skills of alumni, submitting reports and defense memorandums, negotiate, mitigate, and draft contracts and complaints to governmental entities, challenge court decisions, and resort to alternative methods of settling disputes such as arbitration, mitigation, and negotiations skills. ${ }^{133}$

\section{IV.RESOURCES AND ASSESSMENT OF THE EDUCATIONAL PROCESS: ARE THEY SUFFICIENT AND ADEQUATE?}

The resources of the educational process of Egyptian law schools are various and can be divided into physical resources (classrooms, libraries, buildings, libraries) and mental

${ }^{127}$ Id. In practice, most professors usually prefer long essay questions. Many exams include three or four long essay questions with the need of about an hour to answer each one of them.

128 See The Guidebook for National Academic Reference Standards for law Schools (prepared by the NAQAAE), supra note 25 , at 13 (on file with authors).

${ }^{129} I d$. However, as most exams include only memorize-recite questions, it is evident that they seldom assess any of these skills. Unfortunately, they only assess the students' ability to memorize.

${ }^{130}$ Id. (detailing the internal policy of Alexandria, Banha, and 'Ain-Shmas law schools at arts. 7, 15, and 6).

${ }^{131} / d$.

${ }^{132}$ Regrettably, these courses are usually turned into ordinary frontal lectures in which a lecturer does nothing but re-explaining the required textbook and the final exams for these seminars usually include theoretical questions which frequently adopt the long essay format.

133 See The Guidebook for National AcAdemic Reference StANDARDS for LAW Schools, supra note 130 , at 12 . However, alumni are rarely able to gain such skills as both regular legal courses and practical skills sessions are totally focusing on theoretical knowledge transmission. 
resources (conferences, lectures, seminars). The law schools contain large classrooms (natatoriums), computer labs, along with big libraries (for graduate and undergraduate) students library of graduate studies for public law and another for private law for legal research, but we can say that libraries in Egyptian universities are in poor condition. ${ }^{134}$ Universities in Egypt have their dormitories at various places to accommodate male and female students but these buildings suffers from poorly food meals, negligent of hygiene, and bad status of architectural buildings (Imam, 2013) ${ }^{135}$ Likewise, the physical resources of the Egyptian legal institutions generally suffer from various problems such as inadequacy of the classrooms, buildings needs servicing, poor quality of curricula, and the health services was in a bad conditions as well, thus ,both professors and students do not have access to the basic source of academic research and general knowledge. ${ }^{136}$ The educational legal policy based on an integrated educational system which combines elements of virtual using (communication and information technology), distance (video conference), and face-to-face (tutor and student) education in the framework of an integrated educational system. ${ }^{137}$ As for the entertainment facilities, most law schools have a Youth Welfare Office ("YWO") (like the office of students affairs) in charge of achieving pedagogical missions in several activities, this office involves number of committees such as sports, technical, social, and trip committees. ${ }^{138}$

${ }^{134}$ See StUdent Guide Of AleXandRIa University LaW School StUdents, supra notes 23 \& 99, at 50, http://www.higheredsig.org/cihe/Number04-06.pdf \& http://www.higheredsig.org/cihe/Number04-06.pdf. The massive number of students in law schools back to historical reason, at the time of the Ex-President Nasser when he made education free at all levels and expanded the focus to include science and technology, as a result there were targeted effort to increase the student enrolment rates, leading to focus on quantity rather than quality and this caused a decline in quality of education.

135 See generally Hassan Imam, AleXandriA: MosheKLAt BiL-GomlaA(H) [Main Problems], ALAHRAM, Apr. 13, 2013, http://digital.ahram.org.eg/articles.aspx?Serial=1250516\&eid=210 (last visited Jan. 20, 2015). Most libraries in the public universities do not have the necessary funds to update their collections or provide online resources, this is very paradoxical when you consider the fact that Egypt is home to the famous prestigious Alexandria Bibliotheca.

${ }^{136} / d$.

${ }^{137}$ Id. Additionally, the university educational process depends on a way that permits students to apply an individual learning style in order to internalize and obtain deeper learning, via online courses, tutorials, office hours, laboratories, library, and synchronized distant lectures.

${ }^{138}$ See StUdent Guide of AleXANDRia University LAW SCHOol StUdents, supra note 99, at 55 \&56. The new Egyptian Constitution of 2013 provides «Teachers, university professors, and their assistants are the main pillar of education. The State guarantees the development of their academic competencies and professional skills, and care for thier financial and moral rights in order to ensure the quality of education and achieve its objectives and "The State grants the freedom of scientific research and encourages its 
With regard to the faculty members incomes, they are too slight compared to salaries in public and private sector, this is because of lack of funding and almost complete reliance on governmental funding, that lead to inability of the university to pay sufficient salaries to professors which impact the quality of teaching quality according to the recent human rights records. Thus, Egyptian scholars are among the worst paid academics in Arab countries. ${ }^{139}$ As generally well-known, faculty members play an important role in enhancing the quality of legal education, especially with the emerging international standards, as institutional challenges and competitions continue under globalization and the great effect of technology. Recently, it is required by academic legal institutions to pay more attention to enhance faculty member's efficiency through periodical and comprehensive assessment, but there are some problems preventing the improvement of these efficacy and productivity as using traditional teaching means, massive number of admitted students, widespread of private lessons, poor condition of libraries, and inadequate funding. ${ }^{140}$

On the other hand, "Universities specialize in all what is related to the high education and scientific research undertaken by the faculties and institutions of these universities with the purpose of serving society and upgrading a civilized society regarding the contribution to the development in science, human values and providing the society with professionals, technicians, and experts . . the university is considered as a citadel of the human thought and a source for the investment of the most precious wealth in the community which is human wealth." ${ }^{\text {"141 }}$ According to recent legal reports on legal education in Egypt, experts and professionals found that the main purposes of the legal education in Egyptian law schools are as follows:

a.providing society with scientific cadres who are able to satisfy the needs and requirements of the labor market and solve the internal and external obstacles with fair and legal resolutions;

b.spreading the legal culture and ethical legal scientific research;

institutions as a means to achieving national sovereignty, and building a knowledge economy. The State sponsors researchers and inventors, and allocates a percentage of government expenditures that is no less than $1 \%$ of Gross National Product to scientific research. It will gradually increase until it reaches global rates. The State commits to provide effective means of contribution for the private and public sectors and the contribution of expatriate Egyptians to the development of scientific research." See Constitution of the Arab Republic of Egypt, Jan., 2013, supra note 13, at arts. 22 \& 23 (Egypt).

139 They use their free time to teach at private universities or to take high-paying consultancies and therefore have no or minimal time in which to do real academic research, http://portal.unesco.org/education/es/files/51625/11634283495SpringuelEN.pdf/Springuel-EN.pdf.

140 Recently, the government began to encourage the governmental universities to increase their income resources beside their limited income coming from the scholastic charges paid by the students, beside that the estimation affirms that public universities become able to cover about $10 \%$ from their resources through the income obtained by the self-resources such as foreign language departments and the system of opened education.

${ }^{141}$ See generally LAW No. 49 of 1972, supra note 10, at art. 
c.achieving the justice, protection of human rights, and maintaining the stability of legal status (positions) of the persons;

d.to care for the legal researches based on creativity and invention which contribute real recommendations and proposals facing the community, and

e.providing distinguish scholastic programs within the contemporary global trends for both graduate and undergraduate Egyptian and international students. ${ }^{142}$

Egyptian legal academic institutions seeks to achieve these objectives by various measures through increasing the numbers of teaching assistants; improving the textbooks; attaining research via communication means; teaching via online courses; providing the legal libraries with Egyptian and foreign literatures, and increasing the training conferences. Furthermore, creating database environment, providing training courses for the administrative staff, enhancing the electronic system and electronic archiving, aggregating the legal services presented by the faculty and establishing centres for scientific research, increasing the funding sources as the government must support the academic institutions with necessary options and means to achieve its effective educational purposes. ${ }^{143}$ As for final exams, the various internal regulations of the Egyptian law school's determine the exam format as follows:

i.the final exam will be in two semesters and the faculty council can decide oral exams in some courses;

ii.the time amount of the written final exam for any course is three hours, and the university council can modify this time period in special cases;

iii.the maximum number of points for any final exam is twenty (20) points;

iv.the grading assessment calculated as follows:

a."Excellent," (equivalent to the grade of A+, A, and A-) in case of obtaining $90 \%$ of the points of the whole exams or more;

b. "Very good," (equivalent to the grade of B+ and B) in case of obtaining (from $80 \%$ of the points to less than 90\%);

c. "Good" (equivalent to the grade of B-) (from $65 \%$ to less than $80 \%$ ) and "Fairly Good" (from 50\%to less than 65\%);

d. "Weak" (from $35 \%$ to less than 50\%) (equivalent to the grade of C+, C, C, and D) and "Very Weak/Fail" (equivalent to the grade of F) (less than $35 \%$ ) and the final cumulative grade ("GPA") are calculated according to the total points obtained by the student during the four years of the law school. ${ }^{144}$

There is a method for the student to petition his (or her) grade, as each student has the right to appeal the final grade within the time period designated by the law school, otherwise it will not be accepted. ${ }^{145}$ This process is not appropriate as it is limited to

${ }^{142}$ See AleXANDRIA LAW School ANNUAL RePort, supra note 101, at 4.

${ }^{143}$ Id. at $56 \& 57$.

${ }^{144} / d$.

${ }^{145} / d$. This appeal will be achieved according to the modern electronic system begins by going to the office of student affairs to take a card involving a serial number, this card 990 
reassessing the physical errors and mistakes only and making sure that all the questions of the final exam had been graded without seeing whether the instructor was fair or not. ${ }^{146}$ Also, any student committed in cheating or embarking on it during the exam and caught in talobous (flagrante delicto), the dean or (his representatives from any faculty members or proctors) expels the student from the exam room, and deprives him/her from entering the exam, and this student considered failed in the course and subject to the disciplinary board. ${ }^{147}$ Regarding faculty member's appointments and assessment, teaching assistants and assistant lecturers are appointed with decisions from the President of the university based on a request of the school or (the institute)'s council after taking the decision and the appointment is at the date of the decision enactment. ${ }^{148}$ As for the role of the student in evaluating law schools, the universities are responsible for preparing evaluation forms (questionnaires), providing social awareness and training programs for faculty and staff

expires by using it for the appeal, this serial number is written at the website of the faculty designated for that purpose, and then the student selects the grade(s) he or she wants to be reconsidered, the student should retain this card until the result of the appeal is declared, but the appeal is limited to reconsidering the physical mistakes only.

${ }^{146}$ Id.

${ }^{147}$ Id. In 2013, at the Spring semester final exams, there was neurotic delivering the pamphlets of the model answer to eight (8) students inside the examination room at Alexandria law school. The proctors discovered that two of the staff in the school delivers the responses to the students in the exam room, the students had been caught before exchanging these pamphlets with others which were with them, the staff and students were referred to the public prosecution for investigating and revealing the circumstances of this crime. In this regard, the dean declared that the pamphlets of those students for the previous three years will be reviewed to make sure that this crime had not been committed during the previous years, so the law school's administration fights cheating and plagiarism with strict measures and disciplinary penalties.

${ }^{148}$ The appointment of the teaching assistants is after a declaration about vacancies. See generally LAW No. 49 of 1972, supra note 10, at arts. 2, 133, 135, 136, 66, 139, 121, 123, $69,70, \& 198$. To appoint a teaching assistant, he (or she) must be reputable, obtained a general grade of "very good" at least in his or her first law degree, and must have obtained a grade of "good" at least at the hypertext specialization or its substitute. To appoint an assistant lecturer or assistant professor, he (or she) must have obtained the master degree or two diplomas of graduate studies to be qualified for the doctoral program and no declaration needed for appointment. To appoint a full-time faculty member, he (or she) must have obtained a doctoral degree or its substitute from one of the Egyptian universities at specific area of interest or must have obtained it from a foreign university or a scientific institution which is considered equivalent and accredited by the SCU, and reputable. The emeritus professor (reaching the retirement age) is appointed personally at the same school or institute until reaching seventy (70) years old and part-time professors can be appointed by a decision from the university President. To be appointed as an associate professor, the candidate must have a good record of publications or made an excellent constructive work. The same conditions are required for the appointment at the tenured level. Faculty members required to present an annual report about their scientific and academic accomplishments. 
according to the modern evaluation methods. ${ }^{149}$ The recent reports and data declared that it is very important for faculty members in Egyptian and Arab legal and academic institutions to:

(i)to travel for scientific or practical missions (or both of them);

(ii)dispatching them for temporary scientific missions outside the university, and

(iii)enabling them to present at international and national conferences to take knowledge and experience. ${ }^{150}$

As for the disciplinary accountability of the faculty member, the university President determines one of the law school's faculty members at the faculty of law at the same university (or at another university) to hold investigation and cross-examination with the faculty member who have been referred to disciplinary accountability and the dean (or his representatives) can suspend the concerned faculty member based on Case-by-Case basis. ${ }^{151}$

With respect to the institution assessment, the past few years have witnessed a significant perspective of the Egyptian government towards improving the legal education quality. Since 2002, the Ministry of Higher Education ("MHE") have established a higher legal education reform strategy within six main projects, including Quality Assurance and Accreditation Project ("QAAP"), Egyptian Technical Colleges Project (“TCP"), Faculties of Education Enhancement Project ("FEEP"), Information and Communication Technology Project ("ICTP"), Faculty-Leadership Development Project ("FLDP"), and Higher Education Enhancement Project Fund ("HEEPF"). ${ }^{152}$ Nevertheless, the first real steps towards genuine reform pertaining to improvement of quality and efficiency of higher education began with issuing Law No. 82 of $2006^{153}$ which established the NAQAAE which is a governmental authority affiliated to the Prime-Minister and responsible for the accreditation process for all the education institutions in Egypt, including pre-university institutions, faculties, public and private universities along with al-Azhar educational institutions. ${ }^{154}$ Since then, almost all educational institutions have established their own quality assurance units responsible for the internal evaluation process of the institution itself. Accordingly, the quality assurance system in legal education in Egypt comprises:

${ }^{149}$ See AleXANDRIa LAW School ANNUAL RePORT, supra note 101, at 46.

${ }^{150}$ See LAW No. 112 of 1959, supra note 43, at arts. 1 \& 2.

${ }^{151}$ Id., at arts. $105,106,107, \& 110$. The faculty member referred to investigation must be notified with the statement charge (indictment) and a copy of the investigation report and disciplinary sanctions will be implemented in case of conviction (keeping the pension or the reward or the deprivation of one of them pension to the quarter amount).

${ }^{152}$ See generally websites of those projects at http://qaap.net/heep.htm.

${ }^{153}$ See generally LAW No. 82/2006 and its (executive regulation), supra note 43.

${ }^{154}$ See generally PRESIDENTIAL DECREE (in compliance with Law No. 82 of 2006), supra note 25, http://en.naqaae.eg/index.php/services/accreditation. 
(i)an external quality assurance and accreditation process run by the NAQAAE;

(ii)an external quality assurance process run by the SCU and the SCPU, and

(iii) an internal quality assurance process runs by the institution itself, resulting in an annual report prepared by the quality assurance unit and indicating all quality components of the education process.

It is significant to underscore that in case of initial opening of a new law program, the SCU is the only entity responsible for verifying the fulfilment of the required standards and criterions for opening that program. Then, as for the NAQAAE and its considerable role pertaining to improving education quality, it is perfectly covering all aspects of the quality assurance process through adopting three sorts of accreditation schemes, institutional accreditation (schools and faculties including law schools), program accreditation (e-learning, engineering, open education, etc.), and the university. ${ }^{155}$ Seeking to achieve its purposes stated in Article 3 of Law No. 82 of 2006, NAQAAE has to perform three subsequent roles. First, it is responsible for setting the standards of accreditation and education improvement in cooperation with stakeholders. Secondly, it provides the technical support for educational institutions and finally, it issues the accreditation decision after evaluating all the quality aspects. ${ }^{156}$

Concerning to the legal education, NAQAAE published several guidebooks to allow law schools to be aware of all the standards and criterions which have to be met for accreditation. The guidebook for National Academic Reference Standards ("NARS") for law schools (Guidebook, 2015) ${ }^{157}$ and the guidebook for the Accreditation of Higher Education Institution (“AHEI") are considered the most remarkable guidebooks in that field. ${ }^{158}$ Moreover, the accreditation department, which is one of the most important departments of NAQAAE, is responsible for providing advice and guidance regarding technical and administrative matters for all legal educational institution willing to get accredited. ${ }^{159}$ By the same token, and according to Law No. 82 of 2006 and its executive rule, the institution (law school) willing to apply to NAQAAE for accreditation has to fulfil a number of requirements:

(a)obtain a license from the Ministry of Higher Education ("MHE") to operate as an higher education institution;

\footnotetext{
${ }^{155} / d$.

${ }^{156} / d$.

157 See generally The Guidebook for National Academic Reference Standards for LaW SCHOOLS, supra note 130, http://www.naqaae.eg/booklibrary.html?task=view\&id=44\&catid=115 (last visited Jan. 20, 2015).

158 See generally THE GUIDEBOOK FOR THE ACCREDITATION OF HIGHER EDUCATION INSTITUTION, http://www.naqaae.eg/booklibrary.html?task=view\&id=11\&catid=96 (last retrieved Jan. 20,2015 ) (on file with authors).

${ }^{159}$ Id. at 31. See also The Executive Bylaw (issued by) The Presidential Decree No. 25/2007, at art. 5
} 
(b)have an academic certificate, at least, for the educational program required to be accredited;

(c)have a well-documented strategic plan and systems for internal evaluation and annual reports;

(d)submit the agreement of the body to which it is directly affiliated on the accreditation application, and

(e)have a specific, published mission authorized by the governing board. ${ }^{160}$

The law school, is seeking for the accreditation of a program or the institution itself, has to comply with the procedures of the application for accreditation which includes the following steps:

i. The institution should submit an application for accreditation authorized by its governing body besides the governing body of the university to which it is affiliated. If its application has been denied (rejected) due to failing to meet all the previously mentioned requirements, the educational institution will not be allowed to apply again for the next six months.

ii. In case of accepting the application, NAQAAE contacts the intended educational institution urging it to prepare a self-study following the template (sample) provided by NAQAAE. The self-study has to be submitted within six months of the application approval.

iii. The educational institution has to pay the evaluation and accreditation fees determined by the NAQAAE board of directors, and posted on its web site within thirty (30) days of receiving the approval. ${ }^{161}$

It should be noted that NAQAAE has the authority to decide whether the evaluation process will be undertaken by NAQAAE itself or by an individual, a civil society organization or an entity authorized to practice evaluation. ${ }^{162}$ The entity in charge of evaluating the educational process, be it NAQAAE or anyone authorized to do so, must inform the educational institution of the procedures to be followed to accomplish the evaluation process and the dates of the visits to be made by their designated personnel to the institution. ${ }^{163}$ It is to be mentioned that the reviewing committee responsible for evaluating the law school or one of its programs must comprise at least three (3) reviewers. ${ }^{164}$ Moreover, in order to guarantee neutrality, credibility, and independence of the reviewers, the stated law and its executive bylaw provides "that anyone who has business, agency or consultation relation with the educational institution, has a share in the capital of the institution or is related to the top management of the institution or its owners up to the third degree is not allowed to undertake any of its evaluation and accreditation

\footnotetext{
${ }^{160}$ Id. at art. 25.

${ }^{161}$ Id. at art. 6.

${ }^{162}$ See id., LAW No. 82 OF 2006 (and its executive regulation), supra note 25, at art. 6(e).

${ }^{163} / d$.

${ }^{164}$ Id. at The GUIDEBOok fOR ACCREDITATION OF Higher EdUCATION InSTITUTION, supra note 161, at 45 .
} 
work" "The same is true for the members of the boards of trustees, the members of the institution's board of directors, principals, teachers, faculty members and anyone who is a party to a dispute or strife with the institution." 165 In addition, it is stated that "anyone who participated in evaluation and accreditation work is prohibited from giving consultation or advice or training courses to the institution being evaluated or disclosing data and information about evaluation work before the issuance of the Authority's decisions ... and the penalty of violating these prohibitions is a fine of no less than twenty thousand pounds and no more than fifty thousand pounds."166

The aspects to be examined vary according to the subject of evaluation. In case of evaluating the law school itself, the assessment shall include two main domains as follows:

A.Institutional Capacity, which entails strategic planning; organizational structure; leadership and governance; creditability and ethics; administration; resources; community participation, and quality systems management.

B.Educational Effectiveness, which involves graduate and undergraduate students; academic standards; educational program; teaching, learning, and resources; academic staff (faculty members); scientific research; post-graduate Studies, and continuous assessment.

In this domain, if a certain program is to be evaluated, such as open education program, the assessment shall contain program management, which includes three criterions, mission and objectives; leadership, and financial and physical resources, in addition to the educational effectiveness, including assessment of learning outcomes; program development and enhancement along with the indicators of success. ${ }^{167}$ After accomplishing the evaluation within nine (9) months from the date of submitting the accreditation application as stated by law, ${ }^{168}$ NAQAAE informs the law school subject to evaluation with the evaluation results. Its decision varies according to the evaluation result as follows:

i. If the evaluation indicates that the law school has met the established standards, the institution is awarded the accreditation.

ii. If the law school does not meet all the standards, it specifies a period of time it sees necessary to redress the shortcomings, provided that it does not exceed the time period stipulated by the law and NAQAAE obviously identifies the areas which have not met the standards and how to improve in order to reach the required quality level.

iii. If the law school does not obtain the accreditation certificate due to its inability to meet the established standards as indicated by the reports of assessment committees, the status of the institution is referred to the concerned minister, provided that the renvoi (referral) decision comprises the degree of deficit in

${ }^{165}$ Id. at art. $9 \& 23 \&$ art. 15 (the executive bill No. 25/2007), supra note 162.

${ }^{166} / d$.

167 See generally PRESIDENTIAL DECREE (in compliance with Law No. 82 of 2006), supra note 25, http://en.naqaae.eg/index.php/services/accreditation.

${ }^{168}$ Id. at art. 10. 
meeting standards (moderate or severe), the standards which the institution has not applied in addition to what the institution has to do so that it can obtain the accreditation certificate. ${ }^{169}$

In the latter case, the competent minister, after consulting NAQAAE, has the right to take an appropriate measure to correct the conditions of the law school in according to the rules of the law governing it and this includes rehabilitating the law school at its own expenses or obliging it to change its management or stop admitting new students in the different departments of the institution until it meets all standards during one academic year. ${ }^{170}$ Moreover, the law school which failed to obtain accreditation cannot re-apply for the certificate again unless at least a year has passed from the date of the denying decision to award the accreditation certificate, ${ }^{171}$ provided that it gets the approval of the authority to which it is directly affiliated. ${ }^{172}$

It should be emphasized that the accreditation certificate awarded to the law school by the NAQAAE is valid for five (5) years. ${ }^{173}$ It is to be mentioned that the educational institution to which an accreditation certificate is awarded continues, throughout the period of the validity of the certificate, to be subject to periodical monitoring and review through the annual self-reports submitted by the institution and the visits made by the NAQAAE or whoever it authorizes to do so to make sure that the activity, operative system, and educational programs of the institution continue to meet the previously fulfilled evaluation and accreditation standards. ${ }^{174}$ It is worth mentioning in this sense that over the past few years since its creation, the NAQAAE has performed a significant role in the Egyptian legal education system pertaining to raising awareness of educational quality assurance among the Egyptian academic institutes and the Egyptian community as well through setting up educational standards and performance assessment indicators, providing technical assistance for all educational institutions. ${ }^{175}$ Furthermore, it has

${ }^{169}$ Id. at the EXECUTIVE BYLAW No. 25/2007, at art. 6(h).

${ }^{170}$ Id. at LAW No. 82 /2006, at art. 12.

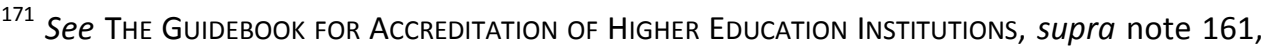
at 54 .

${ }^{172}$ Id. at THE EXECUTIVE BYLAW No. 25/2007, at art. 6(h).

${ }^{173}$ Id. at art. 7.

${ }^{174}$ Id. at art. 8. The accreditation certificate is renewed by the previously mentioned procedures required for applying for the first time. The application for renewing the accreditation certificate has to be submitted within the first month of the last year of the validity period of the certificate.

${ }^{175}$ See generally THE GUIDEBOOK FOR ACCREDITATION OF HIGHER EDUCATION INSTITUTIONS, supra note 16. 
managed to acquire a remarkable reputation concerning its impartial, credible reviewers, and objective assessment. ${ }^{176}$

Furthermore, another external quality assurance process is undertaken by the SCU which is the authority responsible for setting systems of improving and development of educational performance in universities. ${ }^{177}$ Hence, each law school's dean is in charge of preparing a report on the scientific, educational, administrative, and financial process of the institution, comprising all aspects regarding the performance level, the process of education, exams and grades in addition to the difficulties of performance and the proposed convenient proposals and recommendations. ${ }^{178}$

In addition, the governmental attitude of improving education quality has urged all supreme education institutions to establish their own quality assurance units, especially to be able to fulfil the requirements. ${ }^{179}$ Accordingly, the quality assurance unit of a law school is responsible for preparing the strategic plan of the institution and setting mechanisms for activating internal auditing of academic and non-academic activities. ${ }^{180}$ Finally, the quality assurance units operates on supporting the law school councils, which is the governing body of the institution, in defining and achieving the institution's mission and strategic goals and responsible for evaluating the courses and verifying that all educational outputs help achieve the law school mission. ${ }^{181}$ Last but by no means least, preparing the annual self-evaluation review is one of the most imperative tasks of quality assurance units, comprising clarifying strength and weakness points of the institution performance, as each law school is seeking for gradual progress pertaining to improving quality of education through influential internal evaluation with the main objective of obtaining the accreditation certificate from the NAQAAE. ${ }^{182}$

${ }^{176}$ Id. Actually, Mr. Bastwaeesy (one of the contributors to this report) witnessed one of the site visits by the reviewers committee for evaluating Alexandria law school for accreditation. The committee held a session, which was not allowed for the faculty members to attend, for hearing the students' opinions about all the evaluation aspects. All the attending students clarified several shortcomings of the educational process in their law school. The reviewers committee listened carefully for the students bitterly criticizing the faculty members, complaining of the teaching methods and lack of facilities.

${ }^{177}$ See generally LAW No. 49 of 1972, supra note 10, at art. 13(bis).

${ }^{178} I d$. This report is discussed by the law school council which is the governing body of the whole institution in order to be later submitted to the SCU. See REGULATION DECREE No. 809 of 1975, supra note 43, at art. 34(6). However, it is to be mentioned that this kind of evaluation cannot be considered sufficiently effective as it is based on some sort of routine reports without site visits and real assessment of all aspects of educational process. Hence, it rarely results in decisive measures regarding redressing shortcomings.

${ }^{179}$ Id. at LAW No. 82 of 2006, at art. 5.

180 See, e.g., The Quality Assurance Unit at Alexandria LaW School, http://alexlaw.edu.eg/qua/ (last visited Jan. 20, 2015).

${ }^{181} / d$.

${ }^{182} / d$. 


\section{V.Egypt's LEGAL EdUCATIONS FutURE IN THE NEW GLOBALIZED ERA: CONCLUSION AND POLICY RECOMMENDATIONS}

The main cause of deterioration of legal education quality is the lack of a unified national strategic plan for development of higher education in general, and specifically legal education. ${ }^{183}$ By and large, most problems that Egypt encounters can be attributed to two main reasons; corruption and inappropriate managerial system. Accordingly, legal education has always suffered from lacking harmony and even conflict of the public policies and attempts of reform adopted by each higher education Minister. Hence, establishing a National Council of Education and Scientific Research ("NCESR") ${ }^{184}$ has become a necessity with the purpose of preparing a unified national strategic plan for higher education in general, and for legal education in turn, in addition to supervising and verifying the enforcement of such plans. ${ }^{185}$ Change of the governing political party or the Minister of Higher Education should have no effect regarding the implementing process of both short and long run plans pointing at achieving reform in all aspects of higher education. The enormous problem which hinders all the conceivable attempts of enhancing legal education is the enormous number of admitted students compared to the number of the faculty members in each law school. ${ }^{186}$ Hence, it is necessary for the government to seek for achieving rapid and gradual progress regarding three foremost parallel objectives of increasing the number of law schools, reducing the number of admitted students, and appointing (or hiring) more faculty members. ${ }^{187}$ For the first propose, since Egypt suffers from a permanent and increasing budget deficit, it had better

${ }^{183}$ And even if such a plan exists, it may be totally or partially ignored by the Minister of Higher Education and those who are supposed to be responsible for implementation.

${ }^{184}$ Article 214 of the de facto 2012 Constitution provides for the establishment of the national council of education and scientific research which is responsible for preparing a national strategy for all sorts and phases of education, supervising implementing such strategy, and determining the national standards for the quality of education and scientific research. See Constitution of the ARAB Republic of EgYPT, supra note 11, at art. 214. However, the new Constitutional Charter of 2014 has abolished this provision; it is permitted for the Parliament to establish such a council.

185 It should be noted that the Egyptian Cabinet, Information and Decision Support Centre ("IDSC") conducted a survey in February 2009 aimed at measuring faculty member's opinion. The results showed that $91.9 \%$ of the faculty indicated that the most crucial obstacle facing higher education in Egypt is the absence of an obvious strategic plan and lack of clear policies and standards. For further details, see generally THE NATIONAL Higher EdUCATION Statistics PORTAL, Ministry OF HIGHER EdUCATION, http://www.higheducation.idsc.gov.eg/Front/en/suggestions.aspx?goal id=8 retrieved Jan. 20, 2013).

${ }^{186}$ See Higher Education in Egypt Country Review Report, supra note 7, at 22 (chart 3.5 showing the ratio of faculty members to students in social sciences faculties).

${ }^{187}$ Id. 
highly encourage the establishment of indigenous ${ }^{188}$ and waqf (endowment) universities which are two sorts of non-profitable universities established mainly by the efforts and funds of individuals with no or little share from the government (Elshoronbosy, 2005). ${ }^{189}$ In March 2009, the Law of Private and Indigenous Universities No. 12 of 2009 was issued in order to set the legal framework for establishing these sorts of universities (Habib, 2011). ${ }^{190}$ In addition, although the waqf universities experience has achieved unprecedented development of higher education in many countries such as Turkey; especially when such institutions are given a sufficient degree of autonomy regarding financial, administrative and all other aspects, it has not been adopted in Egypt yet. Wakf universities have further pros about guaranteeing a permanent source of income as the constant profit earned from the thing subject to al-shee' al- mawqof (waqf) is devoted to the university. ${ }^{191}$

${ }^{188}$ Cairo University, which is one of the most prestigious universities in the Middle Eastern region and the second university to be established in Egypt after Al-Azhar University, was firstly established as an indigenous one in 1908.

${ }^{189}$ In this regard, the Prophet Mohammed (PBUH) told 'Ummar Ibn Al-Khattab ("[t]ie up the property and devote the usufruct to human beings."). See William F. Fretcher, Islamic Wakf, 36 Mo. L. REV. 2, at 153-155 (1971), http://scholarship.law.missouri.edu/mlr/vol36/iss2/1 ("The institution of wakf rests upon the Shari'a, the religious law of Islam."). Waqf is an inalienable religious endowment in Islamic law, typically donating a building or plot of land or even cash for Muslim religious or charitable purposes. According to Hanafi School of law, waqf "is one of the most eminent Islamic jurists, is the detention of specific thing in the ownership of wakf and the devoting of its profit or products "in charity of the poor or other good objects." The beneficiaries of the waqf can be persons and public utilities and the founder can specify which persons are eligible for benefit (such the founder's family, entire community, only the poor, travellers). Public utilities such as mosques, schools, universities, bridges, graveyards and drinking fountains, can be the beneficiaries of a waqf."). See generally RAMADAN 'AlI AL-SHORONBASY, AHKAM AL-WASYIA WA AL-WAQF FI ALSharie'a Al-Islamia [The General Principles of the Wills, Trusts, and Estates in Islamic SHARIE'A] (2005/Arabic Source).

${ }^{190}$ See generally LAW No. 12 OF 2009 ON PRIVATE AND INDIGENOUS UNIVERSITIES, supra note 10. However, there are only three indigenous universities in Egypt. After issuing this law, only three existing universities applied to be converted to non-profitable indigenous universities. In January 2011, the SCU approved their applications. See Mohammad Habib, Tahweel Gam'aAt El-Nil Wa Al-FrinsiyyaA(H) Wa Al-MisSRyaA(H) ILAa(H) Gam'aAt AHLIYAA(H) [CONVERSION OF EL-NIL, FRENCH, AND Egyptian UNIVERSITIES to ENDOWMENT UNIVERSITIES], AL-AHRAM, Jan. 22, 2011, http://digital.ahram.org.eg/articles.aspx?Serial=417642\&eid=1308 (last visited Jan. 20, 2015). However, the unstable political situation upon the January 25 uprising hindered the accomplishment of required procedures.

${ }^{191}$ See generally Ann Van Wynen Thomas, Note on the Origin of Uses and Trusts-Waqfs, 3 Sw. L. J. 162 (1949), at 164-65. ("Charitable endowments may be formed with particular conservation purposes.") ("In other words, waqf means the permanent dedication by a Muslim of any property for any purpose recognized by the Muslim law as religious, pious or charitable. It allows private contribution to public good as it is not subject to 
On the other hand, in order to achieve the goal on reducing the number of accepted or enrolled students in law schools, there should be a real change of the whole system and admission process adopted regarding allocating students who finished the high school education to higher education institutions. The alternative criteria should put into consideration the requests and abilities of students in order to overcome the reprehensible status quo that a great percentage of law students do not want to study law. Instead, they are just seeking for obtaining a law degree as a way of gaining a preferred social position. Moreover, the SCU should adopt a policy of gradual decline of admitted candidates to join law schools in order to finally reach the international standards regarding the balanced ratio of faculty members to students. This should be in parallel to accommodating more students in vocational education as it is one of the main pillars for achieving an industrial, commercial, and agrarian progress on condition of devoting sufficient support for its augmentation. In the same vein and on appointing (or hiring) more faculty members, the government should devote a higher budget for the higher education Ministry, so that law schools can increase the number of their faculty members. This is more likely to be achieved in the new Egyptian Constitution of 2013 as it "obliges the government to devote at least $2 \%$ of the Gross National Product ("GNP') for governmental expenditure on higher education." 192

Regarding the proposed legislative reforms, Article 13 of Law No. 17 of 1983 on joining the Egyptian Bar Association ("EBA") should be amended in order to require for being an attorney not only to obtain a law degree (LL.B.) but also to pass a certain oral and written exams to verify that the candidate has the minimum required skills and legal knowledge which enable him to practice such a profession. ${ }^{193}$ Moreover, universities' legal statutes should entail explicit provisions prohibiting a law professor to work multiple jobs at the same time. Further, for faculty members who hold administrative posts such as the dean or vice deans (associate deans) of a law school, they should not be permitted to teach any course for students during the period they are holding such a post to which the faculty member usually dedicates most of his (or her) time and effort. Needless to say, the contemporary situation definitely has an extremely negative impact on the educational process in law schools. ${ }^{194}$

Furthermore, on the appointment of the law school's dean and other major posts, it is preferred to be by a virtue of a decree issued by the competent authority upon selecting the

transactions and endowment's yield is devoted to the needy people. Most of the Islamic waqfs are subject to the similar principles and norms and Muslim scholars argued about its details that may reflect on the way of its roles (functions)."). See generally ALSHORONBASY, supra note 192.

192 See id., at Egypt Constitution of 2014, supra note 13, at arts. 21 \& 238.

${ }^{193}$ See LAW No. 17 OF 1983 ON LEGAL COUNSELS, (amended by the Advocates Law and Egypt Bar Association), supra note 35, at art. 13 (explaining the requirements to join the Egyptian Bar Association).

${ }^{194}$ Id. 
best of the candidates for the position who apply to a neutral, credible, impartial, and independent committee. The candidate has to fulfill all the required conditions related to the degree, age, experience, etc. . . . In addition, he (or she) should present his/her ambitious expected policies, achievable plans, and academic strategies for a determined period of time entailing definite objectives in order to be able to assess the extent to which he/she would succeed in implementing his/her plan. On the other hand, the committee members are responsible for the best selected candidate, as he (or she) should satisfy all the requirements which guarantee their neutrality and objectiveness in reaching their selection decision. This technique should be better than the existing method of appointment based on elections, because, in a small community like a law school, the voting process usually relies on personal relations, specific (private) interests, and electorate - the faculty members in our case-would select the candidate who is more likely to achieve their self-interests, without any sort of fairness or objectivity. ${ }^{195}$ Accordingly, upon choosing a candidate who will be responsible for enhancing all aspects of the legal educational process, it had better give up the election system.

At the level of law school, the internal executive regulations and policies should be modified in regard to the curricula. First, theoretical (or doctrinal) courses should place much more emphasis to the highly significant subjects such as intellectual property, environmental protection, international business transactions, consumer law, litigation, comparative law, corporate governance, white collar crimes, and contracts of technology transfer, etc. . . because the sorts and subjects of courses studied in current law schools in the Middle Eastern region, especially Egypt have not changed over decades. Furthermore, there should be genuine development of practical and professional skills seminars (mediation, arbitration, moot courts, legal clinics, etc.) quantitatively and qualitatively so that alumni can attain the necessary expertise to practice any legal profession. This can be brought about through increasing the number of practical courses in addition to adding new forms which deal with actual life-like problems and help students to know much more information about the law's applicability in the real world such as intern and externships, legal colloquiums, etc. For overwhelming the hindrance of massive student body, students can be divided into study groups (workshops) of reasonable number for each and then, groups can join different practical seminars and roundtables reciprocally with a limited period of time for each session. This allows students to enroll and join more practical courses of different important, new legal topics during each semester. It is worth mentioning that development of such courses in quality and quantity is a fundamental technique of overcoming the chronic problem of private tutors which is a prevailing phenomenon in all universities' educational phases especially in legal education. ${ }^{196}$

${ }^{195}$ Previously, the appointment of the law school's dean or (associate or vice deans upon
proposal of the school dean) was by virtue of a decree issued by the university President.
The law did not provide for any further restrictions or requirements pertaining to the
appointment. However, after Egypt Uprisings, Law No. 84 of 2012 provides that "the
three posts of the university President, the dean, and the department's chair shall be
held by virtue of a decree issued by the competent authority according to the result of an
electoral process." In turn, the SCU has issued another decree detailing the requirements
and procedures of such elections. See generally LAW No. 84 OF 2012, Al-Jaridaa(h) Al-
Rasmiyyaa $(h)$ [THE OFFICIAL GAZETTE], June 14, 2012 (Egypt).

${ }^{196}$ Depending on the fact that most courses are theoretical ones and that most exams are memorize-recite ones, frequently adopting long essay questions, a high percentage of students in law schools resort to private tutors who are considered an easy way to 
For promoting the legal knowledge and research capacity of students, law schools should provide libraries with a sufficient number of references including books, dissertations, treatises, law reviews articles, etc. In addition, computer labs should be developed in regard to the number of computers, allowing access to the most significant preferred legal websites such as LexisNexis, Westlaw, Heinonline, etc. which requires paying certain fees in order to help student in their legal writing and researches as well. For achieving real reform regarding the foreign language (English and French) sections, two main aspects should be reconsidered: (a) admitting criteria should not be based solely on the student's score in the secondary (high school) education in the English or French final exam, as there should be an oral and a written test assessing student's actual level and capabilities to study law in different language (than the native one, which is Arabic) and (b) the provision included in most law schools' internal regulations, which stipulates that the content of the courses delivered in the foreign language should not be less than 50 or $60 \%$, has to be enforced as the current real percentage does not even come closer to the required one or by teaching the whole course in the foreign language which the purpose intended for opening these legal advanced programs. Moreover, law schools should provide more scholarships for their junior faculty members to English-speaking countries such as the Unites States, United Kingdom, Canada, etc. because the English legal programs lack the existence of a sufficient number of the faculty members who are capable of teaching in advanced English via using modern techniques in legal research.

On the other hand, the open education program should be abolished from all law schools in the Arabian World because it failed to achieve any of its academic or educational purposes. Unfortunately, it is considered by legal institutions (law schools) as an additional source of income (high tuition fees paid by its students) and by students as a way of obtaining a certificate which may be useful in their existing careers or in their search for one. In addition, the only effective evaluation process of a law school is the one run by the NAQAAE. As a result, there should be a real operative and effective selfevaluation run by the institution itself. A necessary prerequisite for such evaluation is the existence of genuine strategic plans for the law school on both long and short runs. Also, there should be a periodic multi-lateral feedback process, by which the faculty members should feedback on the students and vice-versa, and the faculty members should feedback on the staff and vice-versa, so that there could be a collective evaluation and comprehensive assessment for the law school's status from various perspectives. Additionally, the annual report arranged by the quality assurance unit in each law school should comprise not only the achievements but also the cons and shortcomings with detailed steps to redress and identify solution for each. ${ }^{197}$ The active self-evaluation

pass the final exams as their main role is to abbreviate the (important) topics and legal theories of the textbook assigned in each course to help students in achieving their task of memorizing without arguing much easier. It is to be mentioned that those students usually find it useless to attend classes as they already have the alternative.

197 An obvious example of the ineffective self-evaluation recently realized, is that the annual report of Alexandria University Law School of 2012 was published in 70 pages including only four problems of the legal educational process mentioned in general and without any detailed suggestions or proposals (recommendations by faculty members, staff, and students) to taken into account and deal with. 
necessitates decisive measures of award and punishment for all those who are in charge of the implementing the process in order to guarantee constant progress.

Likewise, law schools should give more attention for the distinguished students. Unfortunately, those students who get the best scores are rewarded only by a sum of money which amounts to 150 Egyptian Pounds (approximately \$40). Hence, such students should receive much more support from their law schools. For example, they may be rewarded by obtaining free additional classes in foreign languages or in legal subjects. Furthermore, they may be allowed to participate in summer study abroad (courses) at the expense of the law school. Moreover, there are personal issues with the faculty, students, and staff, which can be prioritized according to the potential effect on the legal educational system extent and in the shortest period of time possible. All in all, regarding the faculty members, there must be guidance towards the following essential five tasks:

(i) Shifting from the old fashioned and classical (traditional) teaching format, depending on unilateral delivery activity from the side of the instructor, to a multilateral engagement process between the instructor (lecturer) and the students as a whole (professor and students solely and students together) and participate (in suitable class rooms) in an effective discussions, get concepts, notions, roundtable effective ideas, on world concerns and cultural events will be outstanding data. Thus, an advanced quality teaching production is realized, the more cooperative spirit is spread and best creative philosophies are fixed.

(ii) Gradual alteration from the predestined academic textbook in each course to a solitary academic research efforts done by the students by the guidance of the professor and under his (or her) guidelines for the curriculum, to inspire the research and creativity abilities of the student and support his/her legal critical thinking (arguing), enhance writing capability, improve legal writing and research by enabling him/her to get exposed to a variety of thoughts, numerous legal doctrines, and theories.

(iii) Increasing the practical and professional trainings skills by aggregating training courses, practical and applied dimensions in teaching, and the realworld questions (cases) portion in the final exams. There must be concentration on the most frequent legal procedures as memorandum drafting, pleading, advocacy skills, and appeal procedures. By which the student be ready for consultations and defense after his/her graduation.

(iv) General evaluation process depending on more than one written exam in each semester (oral exam, presentations, writing assignments or response papers, attendance, and discussion in class. By which the evaluation process covers the whole dimensions of the student abilities and efforts.

(v) Affording modern technological abilities (libraries and computer labs) to facilitate the study and research process and to accelerate the mutual connection between the various parties to the legal educational process.

From the student's side, the law school must head to make students able to achieve the following: 
(i) Engaging into course-related academic researches (legal writings) solely or with others, to support his/her research skills and critical thinking, and to make arguments and defend these claims in the light of legal theories under the professor's supervision, by which these activities be considered in the evaluation process.

(ii) Involving into more practical activities such as national and international moot court competitions, legal clinics, intern and externships, and studentorganized Non-governmental Organizations ("NGOs"), under both the professor and staff's guidance and assistance to be considered in the assessment process. Also, contributing in opportunities to participate in additional external academic projects such as writing books, law reviews articles, reports, op-eds, etc. Besides, students should have the chance and encouragement to participate in the faculty annual academic magazine, by which they have the opportunity to get their academic and scholarly writings published.

By the same token and as regards to the staff, the following tasks should be attained:

(i) The staff should be constantly under training courses (e.g., Human Resources and Development 'HRD', Information Technology 'IT,' Service and transparency Skills courses, etc.) tracking the latest developments in the administrative and technological environment (electronic archiving) instead of using enormous paperwork.

(ii) The staff hiring and appointment (selection) process should be governed objectively and in neutral way (e.g., degree, credentials, experience, age, languages, general qualifications, etc.) along with effective procedural tracking (e.g., training period) conditions, that offer a minimum level of qualification requirements and, assure that preference is for active managerial efficiency, adequate governance, actual productivity, operative leadership and following code of conducts, and real accountability. The "Award and Punishment" principle should be activated strictly, by which the public official as he (or she) outperforms as he/she will be rewarded or(and) upgraded, irrespective of his (or her) age, and as he/she fails he/she will be subjected to disciplinary sanctions.

(iii) Administrative apparatus (staff) should be equipped with the latest technological tools in public administration to make their tasks easier, faster, and to be accomplished in a well-recognized manner. develop their work electronically (law school's data base), so that it covers all the aspects of the law school and according to a certain deadlines, by which the faculty members can adapt more genuine programs and policies and the students can benefit from this data base.

Last but far not least; because student/mentor relationships are extremely important to student development, authors believe that it very significant at the current moment to create opportunities for law students to participate in research as early as the summer after their freshman year. Even after several years on, it is important for law professors to look 
for additional ways to grow as an instructor and to prevent the teaching from getting stale. Furthermore, it is very substantial to continue looking for opportunities to create new courses, and to fine-tune and update the current courses by incorporating innovative teaching techniques and presenting students the most up-to-date research and theories, as well as historically important work, in each legal area.

The primary purpose for a teacher-researcher (especially law professors and scholars) is to share their love of law and the study of this interesting and fascinating discipline with students, colleagues, and friends. And, this objective can be accomplished by an active, aggressive, creative, and innovative research agenda and well-organized framework, focusing energy and dynamic on own continual growth in areas of teaching and learning, class room management, writing and publishing, and through service of the law school, university, and the international community of scholars and academics which faculty members should affiliated. It is also imperative for legal scholars and faculty members to serve - through actions, professional activities, and personal life-as a role model to students and learners as a devoted scholar, a critical thinker, legal expert, probing academician, and a compassionate humanitarian. The learner-oriented teaching endorses and promotes learning that is both purposeful and enduring. It is the law professor's responsibility to know who his (or her) learners are, what kinds of knowledge and experience they bring to the group, and what they want to achieve so that the faculty can tailor a curriculum that fits their needs and yet leaves enough room to accommodate topics and significant issues that emerge from group discovery. By assessing where learners are concerning the mutual learning objectives, faculty can provide the scaffolding and platform they need to build connections between what they already know and the new understandings they seek to generate. This will stimulate intellectual camaraderie, argumentation, and cooperative problem solving and lay the ground and ethical work for life-long collaborative practice. In summation, the learning process is enhanced by a collegial link between teacher and learner; evident pride in scholarship by the teacher; challenge of the learner's knowledge; illumination of underlying structure by the teacher; active connection between cases and literature by the learner; and mutual feedback. Further, establishing well-reasoned, specific goals for each stage of training, a willingness to be flexible when necessary to meet the individual learner's desires and regular formalized assessment are vital. However, to really transition from a teacher-centered learning environment (classroom) to a more learner-centered environment (wards), students must identify learning needs in themselves, and evaluate their own progress. The authors believe that William B. Yeats captured the exhilaration of teaching when he wrote: "Education is not the filling of a pail, but the lighting of a fire."(Yeats, 2014) $)^{198}$ 